Dabić, M., Vlačić, B., Paul, J., Dana, L. P., Sahasranamam, S., \&

Glinka, B. (2020). Immigrant entrepreneurship: A review and research agenda. Journal of Business Research, 113, 25-38.

https://doi.org/10.1016/j.jbusres.2020.03.013

\begin{abstract}
Immigrant entrepreneurship has become a phenomenon of global interest. This paper reviews existing immigrant entrepreneurship literature in order to map out the major streams of research and identify widely used theories, methods, and contexts. To do this, the authors have reviewed 514 articles from academic journals. This paper highlights the need for interdisciplinary approaches that transcend boundaries. The development and adoption of different theoretical frameworks, the use of multi-level methods, and the consideration of unexplored country contexts are among the authors' recommendations for future research.
\end{abstract}

Keywords: immigrant; entrepreneurship; migration; ethnic minority; multiple correspondence analysis. 


\section{IMMIGRANT ENTREPRENEURSHIP: \\ A REVIEW AND RESEARCH AGENDA}

\section{Introduction}

The United Nations defines a "migrant" as a person who moves to a country other than that of his/her usual residence for a period of at least 12 months (Castles and Miller, 2009). "Immigrant" is the term given to a person who was born abroad, while an immigrant's offspring is termed "second generation" immigrant. This topic is of interest to scholars in various fields, including anthropology, economics, entrepreneurship, management, psychology, sociology, and public policy (Dana, 2007). Immigrant entrepreneurship - generally understood as the undertaking of entrepreneurial activities by immigrants - incorporates tenets of business and sociology, including elements from international entrepreneurship and migration studies. Given the subject's essence and the growing scale of migration phenomena due to globalization, immigrant entrepreneurship has become an important area of research (Nazareno, Zhou, and You, 2018).

The study of immigrant entrepreneurship has been pioneered in popular migration destinations, including the United Kingdom (Patterson, 1963; Ward and Jenkins, 1984), the United States (Bonacich, 1987; Light, 1972; Waldinger, 1984), and Canada (Dana, 1993). Covering the economic aspects of migration, including immigrant entrepreneurship, researchers have gradually explored the various migration processes around the world (Breton, 1964; Dana, 2007). Several scholars have suggested that a lack of language skills, relevant experience, resources, or social embeddedness can hinder business start-ups by immigrants (Constant et al., 2009; Millar and Choi, 2008); however, immigrants sometimes have a higher rate of self-employment than others in their respective host societies (Contreras-Sweet, 2015; Desiderio and Salt, 2010; Levie, 2007). 
Although immigrant entrepreneurship literature is a rather large body of work, existing scholarly literature is highly fragmented and contextual, with many case studies that are ungeneralizable (Dana, 2007) or focused on a specific immigrant group (Barrett and Vershinina, 2017). As observed by Sundarajan and Sundarajan (2015, p. 30), "a lack of synthesized and integrated models has led to [a] fragmented understanding of the true drivers of immigrant entrepreneurship". Models attempting to provide a structured overview fail to explain entrepreneurial paths (Brzozowski, 2017), while others eliminate the distinctiveness of immigrant entrepreneurship (Bailetti, 2018).

This study is the first to attempt to comprehensively review research in this area classifying major themes, mapping them, and identifying widely-used theories, methods, and knowledge gaps. In addition to this, our work highlights the contexts in which the majority of prior studies have been conducted and, in doing so, identifies significant gaps in extant studies. We employ a Multiple Correspondence Analysis (MCA) to examine certain conjectures regarding major research themes, widely used theories, and methods to scientifically review (Hoffman and De Leeuw, 1992). The outcomes are interpreted and scrutinized by the authors in order to make a contribution to the field of immigrant entrepreneurship research.

The structure of this article is as follows. The methodology for the review is described and outlined in the next section. Subsequently, major research themes are identified and discussed. We then highlight the key theoretical underpinnings utilized in the field, along with the dominant methodologies and methods used in prior research. Finally, we offer an integrated discussion and conclusion, including potential directions and recommendations for future research. 


\section{Methodology}

Systematic review papers come in several different forms, namely: structured reviews focusing on widely used methods, theories, and constructs (Rosado-Serrano, et al., 2018; Canabal and White, 2008; Paul and Singh, 2017; Kahiya, 2018); bibliometric reviews (Merigó et al., 2015; Albort-Morant and Ribeiro-Sorriano, 2016; Randhawa et al., 2016; Dabić et al., 2019; Fakhar Manesh et al., 2020); framework based (Paul and Benito, 2018); hybrid-narratives with a framework for setting future research agendas (Paul, Parthasarathy and Gupta, 2017; Kumar, et al., 2019); theory based reviews (Gilal et al., 2019; Paul and Rosad-Serrano, 2019); meta-analysis (Knoll and Matthes, 2017); and reviews seeking model/framework development (Dabić et al., 2017; Paul and Mas, 2019; Paul, 2019). We adopt a hybrid-narrative approach in this paper in order to present the intellectual structure of the research field of immigrant entrepreneurship, subsequently setting an agenda for future research.

\subsection{Selection of articles}

The following criteria were used to select the academic articles. Firstly, we searched for articles that were included in Social Sciences Citation Indexed (SSCI) journals, containing keywords such as 'migrant' OR ‘diaspora' OR 'ethnic' OR 'minority' OR 'disadvantage' AND 'entrepreneur' OR 'self-employment' in the Title, Abstract, or Keywords. ${ }^{1}$ When performing the initial research, we did not impose any restrictions with regards to the year of publication. Accordingly, the initial search resulted in 736 articles, indexed on the SSCI list. In the following phase, we adopted Paul and Rosado-Serrano's (2019) approach and selected only articles published in journals with an Impact Factor above 1.0 (2017 impact factor). This approach was

\footnotetext{
${ }^{1}$ http://mjl.clarivate.com/publist ssci.pdf
} 
generally accepted as influential publications within the field outline empirical and theoretical work and have set new horizons for inquiry (Lopez-Duarte et al., 2016; Chatterjee and Sahasranamam, 2018). In Figure 1, we present the performed methodological protocol.

\section{Insert figure 1 about here}

Following the recommendations of Graneheim and Lundman (2004), the selected articles were reviewed by an international team of six co-authors and two external experts in the field. The final list comprised of 514 articles published in well-recognized journals between 1991 and 2018. We present the entire list of papers in our supplementary material.

\subsection{Building the codebook}

The first stage of the multiple correspondence analysis involved building a codebook containing the main descriptors within the field. Following Furrer et al. (2008) and Ferreira (2011), in order to best examine the overall map of the field, we utilized prior reviews (i.e., Aliaga-Isla and Rialp, 2013; Pogesi et al., 2016) for the development of the initial codebook. We extended this by building a sample of descriptors consisting of 1398 keywords (see full list of keywords according to the major categories in the supplementary material). We adopted the procedure presented in Lopez-Duarte et al. (2016) and, after several rounds of testing by the authors, using QDA Miner v.5 and Wordstat v.7 software, we coded the author-supplied keywords into 20 major categories (see Figure 1). The categories were clustered into four broad themes according to their characteristics: theoretical approaches/frameworks, streams/themes and topics, methodologies used, and geographical context.

The identified themes summarize a large number of idiosyncratic keywords provided by 
authors, prior researchers, and generated databases. The indexed keywords revealed the content of each article, as the authors identified and categorized the keywords that best represented its content to a potential reader. The overview of descriptors that represent the poles of the axes, as well as notable articles representing the poles, is presented in Table 1. In addition to the theoretical foundations' descriptors stemming from the field of immigrant entrepreneurship (see Table 2 in supplementary material), we represented major themes researched in the field (see Table 3 in supplementary material) with methods in line with Aguinis et al. (2009) (see Table 4 in supplementary material) and the geographical distribution of the research fields (see Table 5 in supplementary material).

\subsection{Multiple correspondence analysis (MCA)}

In order to map the field of immigrant entrepreneurship, we conducted multiple correspondence procedures for analyzing qualitative data (Hoffman and De Leeuw, 1992). This approach allowed for the identification of relationships between the dichotomous variables (the presence or absence of the defined keywords in this study). MCA has been widely-used in highly ranked journals and has been recognized as useful in mapping the structure of various research fields such as global strategy (Gonzalez-Loureiro et al., 2015a), strategic management (GonzalezLoureiro et al., 2015b), international strategic alliances and culture (López-Duarte et al., 2016), and cross-border mergers and acquisitions (Kiessling et al., 2019).

The HOMALS analysis was performed in SPSS (v20) software to identify descriptors in the articles' titles, abstracts, and keywords. A value of "1" was entered if the keyword was found and zero if the keyword was absent. The findings of this approach were represented on a proximity map and descriptors were illustrated along the two axes (see Figure 2). Accordingly, the proximity between the descriptors corresponded to shared substance. Where a large proportion of the articles 
within the sample treated the descriptors together, the descriptors were positioned close to each other and vice versa (Bendixen, 1995). Furthermore, the map centres correspond to the average position of all articles within the field (i.e., when the descriptor is positioned close to the centre it shows that a large number of articles within the field are researching this topic).

\section{Mapping the Immigrant Entrepreneurship Research Field}

During the last few decades, immigrant, ethnic, and minority entrepreneurship has kindled a growing interest, as reflected in numerous publications. This research has examined a wide range of entrepreneurial activities, contexts, and specific challenges faced by immigrants and ethnic minorities. The results of HOMALS approach primarily unveiled the theoretical foundations used and research themes within the field (see Figure 2).

\section{Insert figure 2 about here}

In order to provide an up-to-date map of the research field of immigrant entrepreneurship, the dimension poles must be identified (see Table 1) (Hoffman and De Leeuw, 1992). The proportion of variance explained by each pole jointly accounts for $19.2 \%$ of the variance. The variance is usually low as the map synthesizes the information of the $\mathrm{k}$ variables (20 descriptors) in only two dimensions (Furrer et al., 2008; López-Duarte et al., 2016). In line with Hair et al. (1998), Furrer et al. (2008) have noted that variance could have a misleading effect in the MCA approach and that the overall mean of keywords per article, which should be larger than 1, is more meaningful - in our case it is 3.53 .

Insert Table 1 about here 
Accordingly, our results identified (as shown on the far-left horizontal line) the dimension emphasizing immigrant intercultural embeddedness. The articles within this category focus on the intercultural relationships of immigrants (Holt, 1997; Schøtt, 2018) and the embeddedness of the theoretical underpinnings (Kloosterman, 2010). The far-right side of the horizontal dimension indicates a focus on immigrants' motivation to begin and develop entrepreneurial activity (Krueger et al., 2000) as well as the availability and access to resources (Kloosterman, 1999, Edelman et al., 2010). The upper section of the vertical axis identifies the dimension focusing on immigrant entrepreneurial strategies (Bhalla et al., 2006) and internationalization approaches (McHenry and Welch, 2018), while the lower part focuses attention on immigrants' human capital (Honig, 1998). As presented in the map in Figure 2, we were able to identify the core of the immigrant entrepreneurship research field.

Beyond the mapping of the research field, in order to understand it in more depth, it was important to explore three of its main characteristics; namely key themes, theoretical underpinnings, and widely used methodologies. We provide further detail on these three characteristics in upcoming sections. The entire set of 514 papers was considered when developing the basis of key themes, theoretical underpinnings, and methodologies. However, given the large volume of papers, in the interest of space, not all papers will be referred to in the forthcoming discussion. Instead, we adopt a parsimonious approach and refer to a sub-sample of key papers for discussion within subsequent sections. ${ }^{2}$ We would encourage readers to explore the entire list of articles available in our supplementary material.

\footnotetext{
${ }^{2}$ It is suggested that the papers published in the top journals in the field are more likely to push the boundaries of the research field. As such, in subsequent discussions, we will primarily use papers published in top management journals. To identify the top journals, we referred to the Association of Business Schools (ABS) journal ratings of 2018 and considered those journals ranked at level 3 or above.
} 


\subsection{Major themes}

There are six major themes that we can identify following the literature review. These include motives and entrepreneurial intentions; competencies and identity building; ethnic networks; strategies and internationalization; resources; and intercultural relations. We summarize our analysis of each of these themes below.

\section{Theme 1: Motives and entrepreneurial intentions}

Traditionally, immigrants and ethnic minorities have been perceived to be, and shown in research to be, groups with high entrepreneurial motivation (compared to residents of the country). For three decades, researchers have investigated combinations of factors influencing the creations of new ventures by immigrants and ethnic minorities (Dana, 1997; Light and Rosenstein, 1995). Legal or unofficial entrepreneurship is frequently shown to be the immigrants' first choice (Jones, Ram, and Edwards, 2006). Researchers have also claimed that ethnic differences in career choice can be largely explained by self-efficacy and differences in entrepreneurial intentions (Krueger, Reilly, and Carsrud, 2000).

There are theories that explain and explore immigrants' and ethnic minorities' entrepreneurial motives. Among them, two theories that have gained popularity are the disadvantage theory and the cultural theory (Volery, 2007). The disadvantage theory suggests that immigrants set up their own businesses as this is practically the only way that they can earn a living in a new country; it is, therefore, a form of necessity - (forced) entrepreneurship (Chrysostome, 2010; Dana, 1997). However, as some research shows, entrepreneurship can also be a more profitable way of building a professional career in a host country than finding a job in a local labor market (Portes and Rumbaut, 2006). Moreover, Fairlie and Meyer (1996) have shown, based on research in the USA, that an ethnic group's self-employment rate is positively associated with the 
difference between self-employment and wage (salary) for that group. Portes and Zhou (1996), however, have noted that reports in literature concerning the superior or inferior earnings of the self-employed relative to wage/salaried workers are contradictory.

Cultural theories focus on specific characteristics of immigrants, rooted in culture, that make them more inclined towards new venture creation (Berger, 1991; Light and Rosenstein, 1995; Dana et al. 2019). These concepts also discussed the cultural origins of choices of business and industry type (Leung, 2002). Recently, researchers have pointed out that the "entrepreneurial intentions of immigrants are less clear-cut" (Kushnirovich et al., 2017, p. 342). This means that the changing character of migration has resulted in changing patterns of work activities. On the one hand, more high-skilled migrants find their place in the labor market of a host country and, on the other hand, high entrepreneurial motivation is not always translated into the creation of new ventures. This latter phenomenon is described and explained by Kushnirovich and colleagues (2018). They claim that the paradox between immigrants' high entrepreneurial motivation and perceived low likelihood of pursuing entrepreneurship is quite common. The high level of apparent risks (immigration-related) experienced in the past affects immigrants' risk-taking propensity and decreases the perceived feasibility of establishing businesses.

In summary, the origins of entrepreneurial activity of immigrants and/or ethnic minorities are most often rooted in the three following areas (Dana, 1997; Oliveira, 2007): (i) individual characteristics; (ii) social and ethnic networks of immigrants and ethnic minorities and the resources of these groups; and (iii) labor market characteristics in host countries.

In general, motivations for entrepreneurial activity are diverse and must be analyzed in relation to other factors, like general motives for migration and migration strategies. Motives of entrepreneurial activity also influence forms of activity, industry, and business type selection, as 
well as development strategies (Paul and Shrivastava, 2016). Another factor influencing choices concerning the type and scale of ventures relates to the structure of opportunities in the local, host country market (Kloosterman, 2010; Kloosterman and Rath, 2001), as perceived by migrants and constituted by host institutions and the economy. The main dilemma concerns the choice between ethnic and non-ethnic markets. Most publications show that entrepreneurs, at least initially, frequently decide to create ethnic businesses for their own ethnic groups (Castles and Miller, 2009). Furthermore, migrants often judge business opportunities based on their home country experiences, thus finding opportunities that are not attractive for local citizens to be lucrative (Waldinger et al., 1990). Moreover, migrants and ethnic minority members tend to rely on their co-ethnic networks, and this may affect their choices. Often, they decide to enter a sector typical to their ethnic group, or rather imitate other members' group activities and business models. This approach leads to a reduction of perceived uncertainty.

Many researchers have stressed the fact that immigrants, when creating and developing ventures, look for areas with low entry barriers, where they can benefit from their competencies when competing with other enterprises (Bonacich, 1993; Morokvasic, 1993; Waldinger et al., 1990). These traditional activities and stereotypes regarding immigrant businesses are increasingly questioned due to the changing characteristics of migration and the growing diversity of business activities (Leung, 2002). Volery (2007) advocated the need to forgo the 'corner shop' formula and pointed towards the growing diversity of ventures undertaken by migrants. Smallbone, Bertotti, and Ekanem (2005) have argued that Asian-owned firms in the creative sectors exist in contrast with the low value-added nature of many traditional areas of Asian business activity in the UK. There is, however, some evidence that these changes are ostensible, at least partly, and that new migrants are essentially subject to the same structural handicaps as their forerunners 
(Jones et al., 2012), with super-diverse migrants' enterprises hampered by onerous constraints, including racism (Jones et al., 2014).

\section{Theme 2: Competencies and identity building}

Another stream of research is the competencies and identity-building activities of immigrant entrepreneurs (Chrysostome, 2010; Sui et al., 2015). Entrepreneurial competencies are usually broadly defined (Bird, 1995) and include personal characteristics, such as knowledge, skills, motives, and self-efficacy, which influence venture creation and management. Sanders and Nee (1996) note that human capital from the migrant's home country may not be highly valued in the host country's labor market, but immigrants successfully use it to achieve business ownership. Additionally, in the case of immigrants and minorities, mismatches between qualifications and occupation are frequent.

Immigrant- and minority-centred studies very often focus on elements specific to these groups, such as acculturation and adaptation (Berry, 1997), language (Sui et al., 2015), or intercultural skills and competencies (Pecoud, 2004). Researchers have identified that language skills and, in particular, being able to speak the host country's language, can be crucial in making the choice between self-employment and salaried work. Subsequently, language abilities influence the choice of business and target markets. Self-identification processes of immigrant/minority entrepreneurs are also researched. The ways in which entrepreneurs operate and how their decisions can be influenced by a complex system of factors rooted in two contexts are completely discrepant at times. The process of identity creation is complex and is formed by many forces (Heilbrunn et al., 2016). Essers and Benschop (2007) have discussed the micro-politics of identity construction in relation to the categories of gender, ethnicity, and entrepreneurship. 


\section{Theme 3: Ethnic networks}

For over three decades, researchers have analyzed the crucial role of ethnic networks and/or diasporas in immigrants' entrepreneurial activities (Waldinger, 1995; Zimmer and Aldrich, 1987). Existing ethnic groups are frequently treated as a kind of safety network. This is particularly crucial for new migrants, but it is also important for all immigrant entrepreneurs who want to pave their way in the host country's economy (as entrepreneurs or salary workers). For entrepreneurs, such networks can provide financial resources, knowledge on procedures and markets, contacts, and access to potential employees and customers (Kalnins and Chung, 2006, Barnard and Pendock, 2013).

Presence of a social network can be perceived as a factor that partly substitutes access to financial resources and helps overcome difficulties connected with the weak opportunity structures of some immigrant groups (Kloosterman et al., 1999). Moreover, in high-capital sectors, investment, sales, and profits all increase with attachment to migration networks, suggesting that this alleviates capital constraints in those sectors (Woodruff and Zenteno, 2007). It is shown that human capital, personal ties, and family ties facilitate the pooling of labor power and financial resources (Sanders and Nee, 1996). Their research shows that observed inter-ethnic differences in self-employment could be substantially explained by variations in personal human capital and family composition.

However, some researchers demonstrate that the role of ethnic networks is not always so clear and unequivocal (Engelen, 2001; Kalnins and Chung, 2006; Waldinger, 1995). On the basis of a study of Asian immigrants, Bates (1994) argued that the liberal use of ethnic social support networks is typical for less profitable and more failure-prone small businesses. Success and survival stems from large investments and educational credentials rather than ethnic ties. 
Kloosterman and colleagues (1999) have noted that, in order to understand the social position of migrant and minority entrepreneurs, as well as their chances of upward mobility, it is necessary to look beyond co-ethnic networks and take relationships with the wider society into consideration. The role and characteristics of ethnic networks differ depending on the orientation and market strategies of entrepreneurs (ethnic enterprise, serving majority / host country, transnational activities). For example, with transnational activities, the ability to mobilize crosscountry social networks plays a leading role (Portes et al., 2002), whilst for other entrepreneurs ethnic enclave participation may be essential (Portes and Jensen, 1989). Different immigrant communities have different ways of creating, accumulating, and using social capital (Chand and Ghorbani, 2011).

\section{Theme 4: Strategies and internationalization}

As previously mentioned, entrepreneurs' choice of business type is dependent on many factors. Oliveira (2007) suggested that strategies applied by entrepreneurs are created as a result of interaction between three major elements: the characteristics of an entrepreneur, opportunities connected with being a member of an ethnic group, and opportunities connected with functioning within a local community. Many minority or immigrant entrepreneurs decide not to grow and develop their businesses. Those who decide to develop them usually employ one of the following strategies: diversification within an ethnic market, diversification (or moving) outside of an ethnic group, or internationalization.

Waldinger and colleagues (1990) have found that ethnic businesses such as restaurants, grocery stores, or stores with traditional clothing or books in the language of migrants' home country are the first to be created within ethnic communities. When the immigrant community is big enough, entrepreneurs may differentiate their business activities, but still offer products and 
services for their ethnic group. This strategy is safe but creates some serious limitations to development. To overcome these limitations, immigrants may start serving different groups of customers.

Prior research based on the concept of mixed embeddedness (Kloosterman, 2010; Kloosterman and Rath, 2001) has indicated that, aside from individual and social factors (networks), market and opportunities play crucial roles in designing development strategies. According to them, immigrant entrepreneurs can create opportunities by questioning the rules, or introduce innovations on a small, local scale (like Schumpeterian creative destructors). Kloosterman and Rath (2001) have claimed that two dimensions of market opportunities are essential: availability and growth potential. For markets with low availability and low growth potential, it is impossible to build a development strategy that leads to ambitious goals being accomplished. Entrepreneurs willing to develop should thus look for different options.

To some extent, it is natural for immigrant (and ethnic minority) entrepreneurs to internationalize business efforts. Language knowledge can also help with internationalization decisions in their home country or other same-language speaking countries (Sui et al., 2015). Having experiences in two contexts makes establishing links between a host and a home country a desirable and popular means of business development. The transnational perspective in migration studies is built on the assumption of a continuous relationship between immigrants and their home countries, and how this two-way traffic builds complex social and economic fields encompassing two countries (Drori, Honig, and Wright, 2009). Researchers have also pointed out that including migrants and ethnic groups into their analysis may be helpful in facilitating an understanding the general internationalization process.

\section{Theme 5: Resources}


As is the case with entrepreneurship in general, immigrants need access to different types of resources to start and develop their businesses. However, existing research stresses their particular barriers and limitations (Bates and Robb, 2013; Carter et al., 2015; Fraser, 2009, AlDajani, Carter, Shaw, and Marlow, 2015). For instance, the research of Jones et al. (2014) calls these individuals 'under-resourced entrepreneurs' and Baron et al., (2018) uses the term 'underdog entrepreneurs', to highlight the disadvantages of race and ethnicity.

One potential area of these limitations (discussed above) concerns entrepreneurial competencies such as language skills; knowledge about the host country's law, institutions, and economy; and intercultural competencies of migrants and minorities. Other barriers are usually connected with poor access to local financing opportunities. Most researchers demonstrate that barriers and limitations can be partly overcome by the use of social (especially ethnic) networks. Kloosterman et al. (1999) have shown that limited access to financial resources directs entrepreneurs towards the lower end of the opportunity structure and leads to a heavy reliance on social networks. They suggest that insights in terms of resources and opportunities should be combined in research to provide a more comprehensive framework for the analysis of immigrant entrepreneurship.

Sanders and Nee (1996) have argued that network-related resources, e.g. connection with family, are of crucial importance for self-employed immigrants. They developed the concept of forms of capital as the basis of a model for immigrant incorporation (Nee and Sanders, 2001) in order to show how the social, financial, and human-cultural capital of immigrant families predict the sorting of immigrants into various labor market trajectories (entrepreneurship being one of them).

\section{Theme 6: Intercultural relations}


During the last two decades, the number of studies and publications devoted to cultural aspects of entrepreneurship has grown (George and Zahra, 2002; Hayton et al., 2002; Paul and Shrivastava, 2016). Against this background, analysis regarding immigrant entrepreneurship can be considered quite specific, as cultural aspects have long been accounted for in this analysis, often forming one of its main axes.

It has been somewhat automatically assumed that the entrepreneurial activities of immigrants and ethnic minorities are socially embedded (Portes and Sensenbrenner, 1993), while numerous studies have explored particular ethnic groups of immigrants and their methods of dealing with new cultural and economic contexts (Chand and Ghorbani, 2011; Hamilton et al., 2008). In addition to this, immigrants are considered to make up groups contributing to (cultural) diversity, while being highly diverse themselves (super diverse, as suggested by Vertovec, 2007).

While the culture of their country of origin can entice immigrants to establish their own businesses, according to some studies, this is largely determined by the orientation of business activities, as immigrants tend to undertake any activities that are popular, valued, or widely accepted in their country of origin (Basu and Altinay, 2002; Drori et al., 2009). This explains why specific types of business activities seem to be dominant among Asian immigrants, who tend to run restaurants, laundries, or small stores (Leung, 2002). In summary, cultural embeddedness concepts and cultural context analyses form the natural basis for research on immigrant and minority entrepreneurship. In summary, this research focuses on the following areas:

- Cultural reasons for establishing a business (cultural background); culture of the country of origin and cultural background as catalysts for immigrant entrepreneurship (Foreman-Peck and Zhou, 2013; Light and Rosenstein, 1995);

- Culture and social embeddedness as important factors in determining the scale and type of 
entrepreneurial activity; differences in entrepreneurial activities between immigrant groups (Chand and Ghorbani, 2011; Foreman-Peck and Zhou, 2013; Hamilton et al., 2008);

- Assimilation strategies, segmental assimilation, cultural isolation, and their consequences for business development strategies (Hamilton et al., 2008; Portes and Zhou, 1993; Zhou, 2009);

- Intercultural competences, building relationships and one's social capital in a host country (Chand and Ghorbani, 2011; Light, 1972; Light, Bhachu, and Karageorgis, 1993).

\subsection{Theoretical underpinnings}

By reviewing academic literature, we have identified six widely used theoretical frameworks. These include capital theory, embeddedness theory, intersectionality theory, institution theory, culture frameworks, and immigration theories. In this section, we discuss each of these in detail, beginning with some background information concerning the theory, followed by a discussion of a sub-sample of key studies using those theories for immigrant entrepreneurship studies and offering the summary in line with Antecedents, Decision, Outcomes (ADO) framework (Paul and Benito, 2018) in Figure 3. Aside from immigration theories, the other theoretical frameworks discussed below have been used extensively and in entrepreneurship literature as well. Therefore, while discussing each of those theories, we round off our discussion by highlighting the additional value of using each theory to immigrant entrepreneurs' specific context.

\subsubsection{Capital theory}

According to capital theory (Bourdieu, 1986; Dollinger, 1995), human and social capital are key forms of individual capital, and influence business creation (De Clercq, Lim, and Oh, 2013; Sahasranamam and Nandakumar, 2018). Human capital theory discusses the individual value created through education and training (Becker, 1994) and it is argued that entrepreneurs who make substantial investments in their human capital expect their new ventures to be rewarding 
(Marvel, Davis, and Sproul, 2016). Social capital refers to the networks and relationships that entrepreneurs are able to rely on for support (Bhagavatula et al., 2010; Nahapiet and Ghoshal, 1998). In a multiple ethnicities' contexts, Light and Dana (2013) identify the limitations of social capital.

The human capital theory has been used in immigration literature to discuss educational qualifications, skills, international experience, work, and entrepreneurial experience for immigrant entrepreneurship. Through the lens of human capital, Beckers and Blumberg (2013) have studied the effect of human capital and social integration on entrepreneurial success across multiple generations of immigrants. Ndofor and Priem (2011) have argued that immigrant entrepreneurs' stock of economic, human, and social capital influences their venture strategy (focus on ethnic enclave vs. dominant market) and the fit between the two influences venture performance. Others emphasize the interplay between human capital, social capital, and ethnicity in immigrant entrepreneurship (Collins and Low, 2010). Constant and Zimmermann (2006) have found that intergenerational and family factors are more likely to influence self-employment among immigrants in Germany rather than human capital factors. Exploring immigrants' entrepreneurial growth in the UK, Basu and Goswami (1999) have observed that human capital is more important in comparison to financial resources.

Using social capital and network literature, the importance of social networks for immigrants in terms of network structure and strength has been highlighted. Bizri (2017) found that trust and network structure are important in enabling refugee entrepreneurs to maximize the opportunity pool in their host countries. In the case of immigrant entrepreneurs' financing, ethnic ties between venture capitalists and start-up founders have been observed to influence financial decisions in immigrant-led ventures (Bengtsson and Hsu, 2015; Zhang et al., 2016). The role of 
transnational ties on the growth of firms founded by immigrant entrepreneurs has also been researched (Brzozowski et al., 2014).

In summary, we observe that the application of capital theory to immigrant entrepreneurship literature has found similar results to general entrepreneurship literature with regard to the beneficial effect of human and social capital on immigrant entrepreneurs' recognition and exploitation of opportunities (Basu and Goswami, 1999; Bizri, 2017; Ndofor and Priem, 2011). However, we find that immigrant entrepreneurship literature makes additional contributions through its discussion of specific aspects of the human and social capital of immigrant entrepreneurs, namely ethnic knowledge bases, ethnic ties, transnational ties, and others (Ndofor and Priem, 2011; Zhang et al., 2016).

\subsubsection{Embeddedness theory}

The mixed embeddedness approach allows us to explain entrepreneurship by situating entrepreneurial capabilities and opportunities within a socio-economic, spatial and regulatory context (Jones et al., 2014; Kloosterman, 2010; Ram et al., 2013; Stoyanov, 2018). Kloosterman (2010) has developed a framework for analyzing migrant entrepreneurship through a mixed embeddedness approach. From a social embeddedness perspective, having one or more family member in geographical proximity and family financial capital are both seen to improve the likelihood of immigrant entrepreneurship (Bird and Wennberg, 2016). Azmat and Fujimoto (2016) employed the family embeddedness perspective to study Indian immigrant women's entrepreneurship in Australia. The nature of ethnic minority embedding also influences immigrant entrepreneurship entries (de Vries, Hamilton, and Voges, 2015) and growth (Wang and Altinay, 2012). Using the frameworks of ethnic and regional embeddedness, it was noted that ethnic context and economic environment in Sweden played a minor role in understanding individual differences 
in self-employment levels (Ohlsson et al., 2012). Using mixed embeddedness theories in the context of migrant entrepreneurship in London, Sepulveda, Syrett and Lyon (2011) have demonstrated how the interplay between elements of ethnicity and migratory status alongside wider economic and political contexts shape entrepreneurial activities. In short, the use of mixed embeddedness theory in immigrant entrepreneurship brings to forefront discussions on the contextual embedding of ethnic minorities and immigrants, wherein variations are highlighted from native entrepreneurs.

\subsubsection{Intersectionality theory}

Intersectionality literature discusses the privileges and disadvantages emanating from the intersection of social positions of gender, race, and ethnicity (Gill and Larson, 2014; Wang and Warn, 2017). A critical element of intersectionality theory is that intersecting social positions have multiplicative rather than additive effects (Dubrow, 2008; Murzacheva, Sahasranamam, and Levie, 2019). Females and people from ethnic minorities are seen to face significant disadvantages in entrepreneurship (Pio and Essers, 2014; Cheng, 2015). Essers and Benschop (2007) have used the intersectionality theory to explore the complex processes of identity construction for female ethnic minority entrepreneurs. Others have made similar attempts to explore the intersection of gender, ethnicity, and entrepreneurial identity (Barrett and Vershinina, 2017; Hopp and Martin, 2017). In Germany, certain nationalities (such as Turkish migrants) have been observed to benefit from entrepreneurship, while southern Europeans do not have similar outcomes. Similarly, women are observed to have lower earning differentials through self-employment compared to men (vs. wage employment) (Hopp and Martin, 2017).

Entrepreneurship literature in general utilizes intersectionality theory in studying female entrepreneurs or disadvantaged communities (Carter et al., 2015; Murzacheva et al., 2019). The 
context of immigrant entrepreneurship additionally opens up the dimension of ethnicity and migrant status as an intersectional influence on entrepreneurship.

\subsubsection{Institutional theory}

Literature using institutional theory in the study of immigrant entrepreneurship draws arguments primarily from the New Institutional Economics (NIE) perspective of North (1990). According to North, institutions are imperative in structuring human interactions in a society. The institutional framework consists of formal and informal institutions. Formal institutions refer to rules and regulations that control socioeconomic behavior, while informal institutions deal with customs, norms, and social routines. Scott (2001) used these arguments to further categorize institutions into regulatory, normative, and cognitive groups. Regulatory institutions refer to the law and other rules; normative institutions constitute less formal implicit practices; and culturalcognitive institutions represent the most informal, taken-for-granted beliefs. Past research in entrepreneurship has used institutional theory extensively to study venture-creation and growth (Autio and Acs, 2010; Estrin et al., 2016; Sahasranamam and Nandakumar, 2018).

Urbano and colleagues (2011) have highlighted the role of socio-cultural factors in transnational entrepreneurship using multiple case studies from Spain. Institutional theory has also been used to study the moderating role of country-level factors on the individual or firm-level effects on immigrant entrepreneurship. For instance, it is noted that an immigrant's homecountry's institutional characteristics play a crucial role in social ties - influencing performance and relationships in new ventures (Brzozowski et al., 2014). Awaworyi (2017) studied the role of ethnic heterogeneity and institutional environments in entrepreneurial success across countries. Baron et al. (2018) posited that entrepreneurs in a disadvantaged position due to ethnic reasons are more likely to use corruption. 
The use of institutional theory in studying immigrant entrepreneurship closely mirrors scholarly literature on entrepreneurship in general. However, from this review, we observe that the characteristics of immigrants can offer unique contextual level advantages and disadvantages. On the one hand, immigrant status offers beneficial effects with regard to the role of a home-country's institutional support (Brzozowski et al., 2014). At the same time, immigrants are also likely to be underdogs in their host-country's institutional contexts, which leads them to rely on actions (e.g. bribes) that would bridge the disadvantage (Baron et al., 2018)

\subsubsection{Cultural theoretical frameworks}

Hofstede and GLOBE culture frameworks are used to study the role of culture in immigrant entrepreneurship. According to Hofstede (2001), culture refers to the collective mental programming that characterizes members of one group or a category of people and distinguishes them from another. North (1990) conceptualized culture as an informal institution that sets the informal rules or norms, which subsequently incentivize or constrain people's behavior.

Morris and Schindehutte (2005) examined immigrant entrepreneurs from six subcultures in Hawaii and showed that national culture influences the successful creation and growth of entrepreneurial ventures. In a study of immigrant business in London, Basu and Altinay (2002) reported similar findings. Chand and Ghorbani (2011) discuss how the culture orientation of origin countries influence an individual's use of social capital and human resource practices in their ventures. Frederking (2004) highlighted how and when informal institutions reduce transaction costs for immigrant entrepreneurs. Using the lens of language and its role in culture, immigrant ownership is seen to foster global orientation, particularly for French and Allophone owners (Sui et al, 2015). Hofstede and GLOBE frameworks are also used to study the contingent role of country-level factors and individual or firm-level effects on immigrant entrepreneurship. For 
instance, Vinogradov and Kolvereid (2007) have explored the joint effect of human capital and national culture on the self-employment rates of immigrants in Norway.

In summary, we make two key observations with regard to using culture frameworks to specifically study immigrant entrepreneurship. Firstly, we notice that it helps to discuss aspects such an immigrant's home-country's cultural influences on entrepreneurial behaviors (Chand and Ghorbani, 2011; Frederking, 2004; Morris and Schindehutte, 2005). Secondly, it offers a basis for studying how resourcing actions of immigrant entrepreneurs are likely to be different from native entrepreneurs owing to the effects of cultural context (Sui et al., 2015; Vinogradov and Kolvereid. 2007).

\subsubsection{Immigration theories}

Multiple immigration-specific models like transnationalism, economic sociology, and historical perspectives, have also been used when studying immigrant entrepreneurship. Portes and colleagues (2002) have observed transnational entrepreneurship to be an economic adaptation mechanism of immigrants. While exploring transnational social capital, Katila and Wahlbeck (2012) observed that social capital accumulation by immigrant entrepreneurs varies depending on the migration pattern of ethnic groups. From a sociological perspective, Lin and Yang (2017) have found that the pro-trade effect of migrant networks is greater among low-skilled rather than highskilled immigrants. Taking a historical perspective on migration, using data from England, selfemployment rates are seen to be higher among ethnic groups that have a long history of migration and for groups that have arrived more recently (Clark et al., 2017). Storti (2014) integrated new economic sociology, political economy, and neo-institutionalism to analyze the mechanisms through which immigrant entrepreneurship emerges and develops. Using the frameworks of migration history and nationalism, Koning and Verver (2013) studied second- and third-generation 
ethnic entrepreneurs to understand the meaning of ethnicity.

In summary, using the Antecedents, Decision, Outcomes (ADO) framework, we present a conceptual framework summarizing immigrant entrepreneurship literature in Figure 3.

\section{Insert Figure 3 about here}

\subsection{Methodologies used}

A mix of methodologies have been used when studying immigrant entrepreneurs. Quantitative approaches have been used to explore aspects like performance differentiation between immigrant and native entrepreneurs (Hopp and Martin, 2017; Mueller, 2014), the role of family resources (Bird and Wennberg, 2016; Dana et al., 2019), ethnic origins in financing (Cheng, 2015; Zhang et al., 2016), and network relationships (Qin and Estrin, 2015). The methodologies used include regression models (Hopp and Martin, 2017), sequential choice models (Ndofor and Priem, 2011), and event history analysis (Jones, 2001; Qin and Estrin, 2015). The data sources used include government census data (Clark and Drinkwater, 2010; Clark et al., 2017; Fairchild, 2010); other socio-economic surveys (Hopp and Martin, 2017; Sui et al., 2015); data from global organizations (Lin and Yang, 2017), global surveys such as the Global Entrepreneurship Monitor (GEM) (Peroni et al., 2016), or LISA (Bird and Wennberg, 2016); proprietary datasets like Dow Jones (Zhang et al., 2016) or the Kauffman firm survey (Cheng, 2015); and regional or university based surveys (Ndofor and Priem, 2011; Qin and Estrin, 2015).

Qualitative methods have been used to explore social capital in immigrant entrepreneurship (Bizri, 2017; Dana et al., 2019; Katila and Wahlbeck, 2012), ethnic identity in entrepreneurship (Azmat and Fujimoto, 2016; Barrett and Vershinina, 2017), multicultural aspects in immigrant- 
owned firms (Arrighetti, Bolzani, and Lasagni, 2014), processes (Storti, 2014), and the role of embeddedness in resource acquisition by immigrant entrepreneurs (Wang and Altinay, 2012). Studies have used interviews (Arrighetti et al., 2014; Azmat and Fujimoto, 2016; Bizri, 2017), narrative analysis (Barrett and Vershinina, 2017), comparative case studies between immigrant entrepreneur groups (Storti, 2014), ethnography (Koning and Verver, 2013), and grounded theory (de Vries et al., 2015).

Some topics have attracted both quantitative and qualitative approaches. Comparisons between first and second generation immigrant entrepreneurs have employed quantitative (Beckers and Blumberg, 2013) as well as a qualitative methodology (Hamilton et al., 2008). Likewise, the internationalization of immigrant entrepreneurs has been studied quantitatively (Sui et al., 2015) and qualitatively (Light et al., 2013).

\section{Directions for Future Research}

Immigrant entrepreneurship is a vastly developing field of research and the growing number of publications and the increasing diversity of areas covered can be considered as supporting evidence of this. Based on the identification of research gaps, this section is divided into three parts: Future Research Agenda with reference to Approaches, Future Research Agenda with reference to Theory, Methodology, and Context and implications for Policy Makers.

\subsection{Future Research Agenda with Reference to Approaches}

\subsubsection{Holistic and contextualized approach.}

A multidimensional and dynamic phenomenon requires research that will not understate its complexity. The call for meaningful and relevant research, reflecting the multidimensional 
character of this phenomenon, is present in contemporary studies. Ram and colleagues (2017) have argued that a holistic, multi-dimensional approach, testifying to multiple roots of entrepreneurial activities, can be considered the European contribution to this field of research. As these authors have explained, American studies have set the direction of investigation for many decades, supplying aspects and considerations focused on resources (albeit often set within a social context) continue to dominate the field, with only a few exceptions (e.g., Valdez, 2011). Within this trend, Kloosterman (2010), Kloosterman and Rath (2001), and Kloosterman et al. (1999) have developed an appealing theoretical lens of mixed embeddedness. Ram et al. (2017) have argued that this is a breakthrough theory that presents major directions in immigrant entrepreneurship research over the last two decades. Kloosterman (2010) has pointed out that, in immigrant entrepreneurship research, we cannot concentrate only on cultural factors and social capital, as this leads to the overestimation of the supply aspect of the phenomenon and does not allow for a full grasp of its complexity. It is, therefore, necessary to include aspects related to the demand which, in turn, is linked to the structure of the opportunities perceived and capitalized on by entrepreneurs. Consequently, in mixed embeddedness theory, the analysis takes into account actors operating in a specific context (immigrant entrepreneurs) and also the structure of opportunities (Kloosterman, 2010). This concept, therefore, encompasses socially embedded actors, the market, and the institutional framework of the host country. Mixed embeddedness is a concept or research convention that organizes the efforts of researchers and, simultaneously, allows for multiple interpretations - it is non-deterministic.

As described above, many studies take different aspects of the macro-level context into consideration. Culture, market structure, institutional setting, and general economy seem to be dominant here and thus a broad approach has seemed to increase in popularity, providing a general 
picture of the phenomenon. This seems to be a good way to avoid concentration on details that may not be crucial (or even interesting) for other researchers, managers, policymakers, etc. (Combs, 2010). This, however, creates a challenge: to remain meaningful without being too detailconcentrated, and to provide evidence that fills existing gaps in knowledge concerning immigrant entrepreneurship. Moreover, we agree with Aliaga-Isla and Rialp (2013) in that research combining different levels of analysis (macro and micro) is still relatively scarce.

\subsubsection{Interdisciplinary approach.}

Primarily, it should be stressed that, by its very nature, research into immigrant entrepreneurship revolves around several disciplines. As we treat immigrant entrepreneurship as a distinct, specific field of research within organization and management theory, we see these influences as a potential source of novel and valuable interpretations. However, as in any other field, borrowing theories from other disciplines brings benefits, but also potential threats, such as misfits, biased interpretations, and misinterpretations (Oswick, Fleming, and Hanlon, 2011). In other words, to make borrowing useful, careful analysis and adjustments are needed. We believe that in immigrant entrepreneurship careful blending can take place. Below, we mention selected disciplines which have had clear and visible influences on researchers, however it is worth noting that many articles on this topic have been published in journals in the fields of geography, urban studies, and anthropology, among others.

Researchers draw inspiration from sociology to a large degree. Concepts connected with motives of entrepreneurship, such as disadvantage and cultural theories (Chrysostome, 2010; Volery, 2007), or concepts of social capital (Portes et al., 2002; Waldinger, 1995), widely used in studies, are derived from sociology. Some researchers postulate the utilization of classical sociological theories (such as Weber's theory) to advance investigations (Engelen, 2001). 
Moreover, many of the most frequently quoted papers were published in sociological journals, such as the American Sociological Review, and belong - at least partly - to that discipline (e.g., many of Alejandro Portes' publications).

Economics is another field strongly influencing researchers, with many articles published in notable economic journals (Small Business Economics, World Development, etc.). In this case, however, the economy serves as a background rather than a major source of theories and perspectives. Some popular and frequently used concepts in both economics and management are applied (such as transaction costs; e.g., Yang et al., 2012).

Psychology also marks its presence in micro-level analysis, such as entrepreneurial competencies. Personal characteristics, self-efficacy, and other elements of competencies are directly derived from psychological theories. Other concepts and schools of psychology, including evolutionary psychology, are also applied in the area of immigrant entrepreneurship (Yang et al., 2011).

Finally, many studies draw inspiration from other fields within management and entrepreneurship. Here, the most popular concepts transferred to immigrant entrepreneurship are those created within the strategic management field, like a resource-based perspective (Shinnar et al., 2011; Yang et al., 2012) or networks and inter-organizational relations. In addition to this, the most natural base for inquiry is general entrepreneurship, with concepts like opportunity, entrepreneurial orientation, or entrepreneurial processes. We believe that stronger utilization of concepts from other fields of management may be useful in enriching our understanding of immigrant/minority businesses. We would suggest diverting more attention particularly on the analysis of strategy formation, strategizing, inter-organizational relations, organizational development, and internal organization (design) of such businesses. Generally, an intelligent 
combination of theories and concepts from different disciplines can lead to a more meaningful and systematic way of presenting the phenomenon.

\subsection{Future Research Agenda}

Following the approach seen in prior reviews (Paul et al., 2017; Rosado-Serrano et al., 2018) we provide directions for future research using Theory, Methodology, and Context (TMC) frameworks.

\subsubsection{Theory}

As highlighted above, immigrant entrepreneurship research has drawn on multiple theories, including capital theory, embeddedness approach, intersectionality view, institutional theory, culture frameworks, and sociological views. In recent years, studies have increasingly used multitheoretical approaches to understand immigrant entrepreneurship (Dana and Morris, 2010). Moreover, studies that jointly consider individual and environmental effects are needed to advance the field. For instance, following Katila and Wahlbeck (2012), the integration of migration and capital theories could explore the role of migration in the development of entrepreneurship clusters and its subsequent role in the economy. Conflict-generated immigrants are observed to exhibit different behaviors (Koinova, 2011). In the backdrop of many such immigrants generated through conflicts (e.g., India-Pakistan, Sri Lanka in south-east Asia) and others, closer attention to entrepreneurship from immigrants is required. In particular, future research could use migration and psychological theories to uncover the role of psychological factors such as stigma on immigrant entrepreneurship. We observed limited use of psychological theories in discussions on immigrant entrepreneurship, despite the general acknowledgement that the psychology of immigrants is different (Mahalingam, 2006).

The literature at the intersection of entrepreneurship and geography has been a topic of 
interest over the last decade, with increasing discussions on concepts such as entrepreneurial ecosystems. This opens up the possibility for researchers to explore the role of entrepreneurship support mechanisms like incubators and accelerators on immigrant entrepreneurship. These support new ventures through intensive mentoring, networking opportunities, and (often) financing (Audretsch et al., 2011). As previously mentioned, there is already evidence suggesting that ethnic group ties play an important role regarding financing (Bengtsson and Hsu, 2015; Zhang et al., 2016). As an extension of this, it would be interesting to examine the role of immigrant characteristics in attracting support from incubators/accelerators. In countries like the UK, university-incubators offer immigrant student entrepreneurs an initial landing pad (through visa sponsorship and seed funding) to remain in the country to start and grow new ventures (e.g., Tier 1 Graduate Entrepreneur Visa Scheme at multiple UK universities). Academic research into the effectiveness of such schemes and their impact on promoting entrepreneurship is needed.

Finally, the use of theories such as signaling theory and resource-based view (RBV) could enhance our understanding of how different external stakeholders view immigrants in financing or resource provisioning decision processes. As such, supporting evidence exists concerning the role of government support on ethnic businesses (Deakins et al., 2009) and the influence of ethnic networks on financing immigrant enterprises (Zhang et al., 2012). With the emergence of a number of new financing mechanisms, such as crowd funding, mini-bonds, government venture capital, and angel networks etc. (Block et al., 2018), one promising area for future research would be the use of signaling theory to evaluate the ways in which these emerging forms of financing influence immigrant entrepreneurs.

There is also scope for thinking beyond the GLOBE and Hofstede theoretical models, as they have been repeatedly researched. There are opportunities to use newly developed models, 
such as the 7-P framework, for internationalization grounded in potential, path, process, pace, problems, pattern, and performance (Paul and Sanchez-Morcillo, 2019), or SCOPE frameworks (Paul, 2020) to carry out future research in this area. Researchers could analyze some of the Pconstructs of immigrant entrepreneurs, such as path, pattern, and pace. Comparative studies analyzing the performance of immigrant entrepreneurs alongside locally born business owners would also be interesting.

\subsubsection{Methodology}

Most immigrant entrepreneurship research is empirical in nature, relying on quantitative approaches. Based on the works of Essers and Benschop (2007) and others, given the contextual relevance of immigrant entrepreneurship, we suggest that, in order to advance theoretical development and facilitate a nuanced understanding of the phenomenon, there is a need to adopt more qualitative methods, e.g., grounded theory, historical narrative, and/or phenomenology. The use of a mixed-methods approach, rare to date, is encouraged as well. We believe that such approaches could be beneficial as a result of the need for both generalizations and deep insights into the field.

Most of the quantitative research on immigrant entrepreneurship has been based on datasets collected by governmental organizations and, in some cases, from global surveys. These methods do not track immigrant entrepreneurs over long periods. Therefore, we have a limited understanding of how immigrant entrepreneurship evolves over different phases of a venture. Scholars have argued for the presence of multiple legitimacy thresholds within a new venture's evolution (Fisher et al., 2016; McKnight and Zietsma, 2018). Immigrants, in most instances, face not only venture legitimacy concerns, but also liabilities of foreignness. In order to understand how immigrants, overcome such concerns, it is important to track them through different phases 
of their venture. To this end, longitudinal surveys of immigrant entrepreneurs are essential.

From our literature review, we observe that immigrant entrepreneurs are uniquely influenced by aspects such as the ethnic characteristics of their families, the perceptions towards their country-of-birth of parents, and differences in culture between their country of operation and their ethnic origin. In order to understand the role of individual characteristics in conjunction with family-, community-, and country-level factors, the use of multi-level methodological approaches, such as Hierarchical Linear Modelling (HLM) and Multi-Level Structural Equation Modelling (ML-SEM), are recommended. These methods have been observed to be sparsely used in extant research. The absence of considering such multi-level approaches leads to ecological fallacy problems. Such problems arise when conclusions regarding individual behaviors are derived based on aggregated data (Robinson, 1950).

\subsubsection{Context}

As highlighted, most research on immigrant entrepreneurship has focused on immigrants within market contexts such as North America, Europe, and Asia. Given the rapid rise of entrepreneurship in emerging markets (Sahasranamam and Sud, 2016), future research needs to look into immigrant entrepreneurship in emerging markets particularly within a southern hemisphere context. These contexts are characterized by institutional voids and a limited history of entrepreneurship (Khanna and Palepu, 2006; Sahasranamam and Ball, 2018), which researchers could capitalize on for advancing context-specific immigrant entrepreneurship research.

A number of new ventures have been initiated by immigrants from developed countries in Africa, Oceania, and Latin America, specifically in the social entrepreneurship space (e.g., Jamii Bora, microfinance in Kenya) (Littlewood and Holt, 2018; Rivera-Santos et al., 2015). Many such 
ventures have also managed to attract grants or other forms of financial support from global developmental organizations and philanthropic foundations, such as DFID, the World Bank, or the Rockefeller Foundation. This provides excellent opportunities for studying immigrant social entrepreneurship and the role of developmental organizations.

Another context that is ripe for future research is immigrant entrepreneurship specifically in developed country contexts, which have been generous in their migration policies for refugees from conflict-affected areas. Such entrepreneurs would have very different human and social capital to rely upon while living as refugees in comparison to skilled migrants. Exploring such differences in capital, coupled with the history of migration and other institutional contextual factors, would make a key contribution to literature in this area.

There is also need for future research to explore immigrant entrepreneurship at a subnational level. For instance, within large emerging markets, such as China and India, there are subregions that are more cosmopolitan (e.g., Mumbai or Bengaluru in India, Shanghai in China) compared to other regions and are observed to be influential on entrepreneurial activity (Bhagavatula et al., 2019; Chatterjee \& Sahasranamam, 2018). Similarly, factors such as regional entrepreneurial culture, community deprivation, and city characteristics are known to influence entrepreneurship (Murzacheva et al., 2019; Qian, 2017). Scholars need to build on such research into sub-national characteristics in order to understand how these sub-national aspects influence immigrant entrepreneurship.

\subsection{Implications for Policy Makers}

Immigration and entrepreneurship are both subject matters of great interest for policy makers, given their influence on economic development. For instance, immigrant entrepreneurs are considered to be more entrepreneurial than home-nationals (in the U.K., for example, see Hart, 
Bonner, and Levie, 2016) and are likely to offer a significant boost to the economy (Kerr and Kerr, 2016). Through this literature review, we provide a comprehensive understanding of immigrant entrepreneurship. This will help policy makers to assume an integrative view while developing regulations and other support infrastructures for the promotion of immigrant entrepreneurship.

\section{Conclusion}

This review takes stock of the research on immigrant entrepreneurship, maps it using multiple correspondence analyses, and offers directions for future researchers with regard to theories, methods, and contexts. Based on the integrative review, we have revealed six major research themes and focal theoretical foundations of the field of immigrant entrepreneurship. Given the relevance of immigrant entrepreneurship for job creation and wealth creation (Kerr and Kerr, 2016), it is important that we advance knowledge creation in this field in terms of the theories, concepts, and methods used when studying in this area. In this regard, we hope that this review will bring about renewed vigor and interest in researching immigrant entrepreneurship. 


\section{References}

Akcigit, U., Grigsby, J., \& Nicholas, T. (2017). Research: Immigrants played an outsize role in America's age of innovation. Harvard Business Review. Retrieved from https://hbr.org/2017/04/research-immigrants-played-an-outsize-role-in-americas-age-ofinnovation

Albort-Morant, G., \& Ribeiro-Soriano, D. (2016). A bibliometric analysis of international impact of business incubators. Journal of Business Research, 69(5), 1775-1779.

Al-Dajani, H., Carter, S., Shaw, E. \& Marlow, S. (2015). Entrepreneurship among the Displaced and Dispossessed: Exploring the Limits of Emancipatory Entrepreneuring. British Journal of Management, 26(4), 713-730.

Aliaga-Isla, R. \& Rialp, A. (2013). Systematic review of immigrant entrepreneurship literature: previous findings and ways forward. Entrepreneurship and Regional Development, 25(9-10), 819-844.

Arrighetti, A., Bolzani, D. \& Lasagni, A. (2014). Beyond the enclave? Break-outs into mainstream markets and multicultural hybridism in ethnic firms. Entrepreneurship \& Regional Development, 26(9-10), 753-777.

Audretsch, D. B., Aldridge, T. T. \& Sanders, M. (2011). Social capital building and new business formation: A case study in Silicon Valley. International Small Business Journal, 29(2), 152-169.

Autio, E. \& Acs, Z. J. (2010). Intellectual property protection and the formation of entrepreneurial growth aspirations. Strategic Entrepreneurship Journal, 4(4), 234-251.

Awaworyi Churchill, S. (2017). Fractionalization, entrepreneurship, and the institutional environment for entrepreneurship. Small Business Economics, 48(3), 577-597.

Azmat, F. \& Fujimoto, Y. (2016). Family embeddedness and entrepreneurship experience: a study of Indian migrant women entrepreneurs in Australia. Entrepreneurship \& Regional Development, 28(9-10), 630-656.

Bailetti, E. (2018). Transnational entrepreneurship: Distinctive features and a new definition". Technology Innovation Management Review, 8(9), 28-38.

Barnard, H. \& Pendock, C. (2013). To Share or Not to Share: The Role of affect in knowledge sharing by individuals in a diaspora. Journal of International Management, 19(1), 47-65.

Barrett, R. \& Vershinina, N. (2017). Intersectionality of ethnic and entrepreneurial identities: A study of Post-War Polish entrepreneurs in an English city. Journal of Small Business Management, 55(3), 430-443.

Basu, A., \& Altinay, E. (2002). The interaction between culture and entrepreneurship in London's immigrant businesses. International Small Business Journal, 20(4), 371-393.

Basu, A., \& Goswami, A. (1999). Determinants of South Asian entrepreneurial growth in Britain: A multivariate analysis. Small Business Economics, 13(1), 57-70. 
Bates, T. \& Robb, A. (2013). Greater access to capital is needed to unleash the local economic development potential of minority-owned businesses. Economic Development Quarterly, 27(3), 250-259.

Bates, T. (1994). Social resources generated by group support networks may not be beneficial to Asian immigrant-owned small businesses. Social Forces, 72(3), 671-689.

Baum, J. R. \& Locke, E. A. (2004). The relationship of entrepreneurial traits, skill, and motivation to subsequent venture growth. Journal of Applied Psychology, 89(4), 587-598.

Becker, G. S. (1994). Human capital: A theoretical and empirical analysis with specific reference to education. Chicago: University of Chicago Press.

Beckers, P. \& Blumberg, B. F. (2013). Immigrant entrepreneurship on the move: A longitudinal analysis of first- and second-generation immigrant entrepreneurship in the Netherlands. Entrepreneurship \& Regional Development, 25(7-8), 654-691.

Bengtsson, O. \& Hsu, D. H. (2015). Ethnic matching in the U.S. venture capital market. Journal of Business Venturing, 30(2), 338-354.

Berger, B. (Ed.) (1991). The Culture of Entrepreneurship. San Francisco: ICS Press.

Berry, J. W. (1997). Immigration, acculturation, and adaptation. Applied Psychology, 46(1), 5-34.

Bhagavatula, S., Elfring, T., van Tilburg, A. \& van de Bunt, G. G. (2010). How social and human capital influence opportunity recognition and resource mobilization in India's handloom industry. Journal of Business Venturing, 25(3), 245-260.

Bhagavatula, S., Mudambi, R., \& Murmann, J. P. (2019). Innovation and Entrepreneurship in India: An Overview. Management and Organization Review, 15(3), 467-493.

Bhalla, A., Henderson, S. \& Watkins, D. (2006). A multiparadigmatic perspective of strategy: A case study of an ethnic family firm. International Small Business Journal, 24(5), 515-537.

Bird, B. (1995). Toward a theory of entrepreneurial competency. In J. A. Katz \& B. R.H. (Eds.), Advances in Entrepreneurship, Firm Emergence, And Growth (Vol. 2): JAI Press.

Bird, M., \& Wennberg, K. (2016). Why family matters: The impact of family resources on immigrant entrepreneurs' exit from entrepreneurship. Journal of Business Venturing, 31(6), 687704.

Bizri, R. M. (2017). Refugee-entrepreneurship: A social capital perspective. Entrepreneurship \& Regional Development, 29(9-10), 847-868.

Block, J. H., Colombo, M. G., Cumming, D. J. \& Vismara, S. (2018). New players in entrepreneurial finance and why they are there. Small Business Economics, 50(2), 239-250.

Bonacich, E. (1987). "Making it" in America: A social evaluation of the ethics of immigrant entrepreneurship. Sociological Perspectives, 30(4), 446-466.

Bonacich, E. (1993). Asian and Latino immigrants in the Los Angeles garment industry: an exploration of the relationship between capitalism and racial oppression. In I. Light \& P. Bhachu (Eds.), Immigration and entrepreneurship. Culture, capital and ethnic networks (pp. 51-74). New Brunswick, USA \& London, UK: Transaction Publishers. 
Bourdieu, P. (1986). The forms of capital. In J. Richardson (Ed.), Handbook of Theory and Research for the Sociology of Education (pp. 241-258). Westport: Greenwood.

Breton, R. (1964). Institutional completeness of ethnic communities and the personal relations of immigrants, American Journal of Sociology, 70(2), 193-205.

Brzozowski, J. (2017). Immigrant entrepreneurship and economic adaptation: A critical analysis". Entrepreneurial Business and Economics Review, 5(2), 159-176.

Brzozowski, J., Cucculelli, M. \& Surdej, A. (2014). Transnational ties and performance of immigrant entrepreneurs: the role of home-country conditions. Entrepreneurship \& Regional Development, 26(7-8), 546-573.

Canabal, A., \& White III, G. O. (2008). Entry mode research: Past and future. International Business Review, 17(3), 267-284.

Carter, S., Mwaura, S., Ram, M., Trehan, K. \& Jones, T. (2015). Barriers to ethnic minority and women's enterprise: Existing evidence, policy tensions and unsettled questions. International Small Business Journal, 33(1), 49-69.

Castles, S. \& Miller, M. J. (2009). The Age of Migration: International Population Movements in the Modern World: Palgrave Macmillan Limited.

Chand, M. \& Ghorbani, M. (2011). National culture, networks and ethnic entrepreneurship: A comparison of the Indian and Chinese immigrants in the US. International Business Review, 20, 593-606.

Chatterjee, D. \& Sahasranamam, S. (2018). Technological innovation research in China and India: A bibliometric analysis for the period 1991-2015. Management and Organization Review, 14(1), 179-221.

Chena, C.C., Greenebe, P.G. \& Crickc, A. (1998). Does entrepreneurial self-efficacy distinguish entrepreneurs from managers? Journal of Business Venturing, 13(4), 295-316.

Cheng, S. (2015). Potential lending discrimination? Insights from small business financing and new venture survival. Journal of Small Business Management, 53(4), 905-923.

Chrysostome, E. (2010). The success factors of necessity immigrant entrepreneurs: In search of a model. Thunderbird International Business Review, 52(2), 137-152.

Clark, K. \& Drinkwater, S. (2010). Patterns of ethnic self-employment in time and space: evidence from British Census microdata. Small Business Economics, 34(3), 323-338.

Clark, K., Drinkwater, S., \& Robinson, C. (2017). Self-employment amongst migrant groups: new evidence from England and Wales. Small Business Economics, 48(4), 1047-1069.

Collins, J., \& Low, A. (2010). Asian female immigrant entrepreneurs in small and medium-sized businesses in Australia. Entrepreneurship \& Regional Development, 22(1), 97-111.

Combs, J. G. (2010). Big samples and small effects: Let's not trade relevance and rigor for power. Academy of Management Journal, 53(1), 9-13.

Constant, A., \& Zimmermann, K. F. (2006). The making of entrepreneurs in Germany: Are native men and immigrants alike? Small Business Economics, 26(3), 279-300. 
Constant, A., Kahanec, M. \& Zimmermann, K. (2009). Attitudes towards immigrants, other integration barriers, and their veracity. International Journal of Manpower, 30, 5-19.

Contreras-Sweet, M. (2015). Immigrant entrepreneurs help fuel record growth streak. https://www.sba.gov/blogs/immigrant-entrepreneurs-help-fuel-recordgrowth-streak. Accessed 31 October 2019.

Dabić, M., Mikulić, I., \& Novak, I. (2017). Framing research at the tourism and terrorism nexus. Acta turistica, 29(2), 181-212.

Dabić, M., Maley, J., Dana, L. P., Novak, I., Pellegrini, M. M., \& Caputo, A. (2019). Pathways of SME internationalization: a bibliometric and systematic review. Small Business Economics, 121.

Dana, L. P. (1993). An Inquiry into Culture and Entrepreneurship: Case Studies of Business Creation among Immigrants in Montreal, Journal of Small Business \& Entrepreneurship 10(4), 16-31.

Dana, L. P. (1997). The origins of self-employment in ethno-cultural communities: Distinguishing between orthodox entrepreneurship and reactionary enterprise. Canadian Journal of Administrative Sciences, 14(1), 52-68.

Dana, L. P. (2014). Asian Models of Entrepreneurship - From the Indian Union and Nepal to the Japanese Archipelago: Context, Policy and Practice, Second Edition, Singapore \& London: World Scientific.

Dana, L. P. (ed.) (2007). Handbook of research on ethnic minority entrepreneurship. A coevolutionary view on resource management. Cheltenham, UK: Edward Elgar.

Dana, L. P., \& Morris, M. (2010). Ethnic minority entrepreneurship. In Dana L.P. (Ed.), World Encyclopedia of Entrepreneurship. Cheltenham, Edward Elgar, pp. 149-157.

Dana, L. P., Gurau, C., Light, I. and Muhammad, N. (2019). Family, Community, and Ethnic Capital as Entrepreneurial Resources: Toward an Integrated Model. Journal of Small Business Management, published online ahead of print: https://doi.org/10.1111/jsbm.12507

De Clercq, D., Lim, D. S. K., \& Oh, C. H. (2013). Individual-level resources and new business activity: The contingent role of institutional context. Entrepreneurship Theory and Practice, 37(2), 303-330.

de Vries, H. P., Hamilton, R. T., \& Voges, K. (2015). Antecedents of ethnic minority entrepreneurship in New Zealand: An intergroup comparison. Journal of Small Business Management, 53, 95-114.

Desiderio, M. V. \& J. Salt (2010) Main Findings of the Conference on Entrepreneurship and Employment Creation of Immigrants in OECD Countries. Paris: OECD.

Dollinger, M. J. (1995). Entrepreneurship: Strategies and resources. Boston, MA: Prentice Hall.

Drori, I., Honig, B., \& Wright, M. (2009). Transnational entrepreneurship: An emergent field of study. Entrepreneurship: Theory and Practice, 33(5), 1001-1022.

Dubrow, J.K. (2008). How can we account for intersectionality in quantitative analysis of survey data? Empirical illustration of Central and Eastern Europe. ASK: Society, Research, Methods, $17,85-102$. 
Edelman, L. F., Brush, C. G., Manolova, T. S., \& Greene, P. G. (2010). Start-up motivations and growth intentions of minority nascent entrepreneurs. Journal of Small Business Management, 48(2), 174-196.

Engelen, E. (2001). Breaking in' and 'breaking out': A Weberian approach to entrepreneurial opportunities. Journal of Ethnic \& Migration Studies, 27(2), 203-223.

Essers, C. \& Benschop, Y. (2007). Enterprising identities: Female entrepreneurs of Moroccan or Turkish origin in the Netherlands. Organization Studies, 28(1), 49-69.

Estrin, S., Mickiewicz, T. \& Stephan, U. (2016). Human capital in social and commercial entrepreneurship. Journal of Business Venturing, 31(4), 449-467.

Fairchild, G. B. (2010). Intergenerational ethnic enclave influences on the likelihood of being selfemployed. Journal of Business Venturing, 25(3), 290-304.

Fairlie, R. W. \& Meyer, B. D. (1996). Ethnic and racial self-employment differences and possible explanations. Journal of Human Resources, 31(4), 757-793.

Fakhar Manesh, M., Pellegrini, M. M., Marzi, G., \& Dabic, M. (2020). Knowledge Management in the Fourth Industrial Revolution: Mapping the Literature and Scoping Future Avenues. IEEE Transactions on Engineering Management. https://doi.org/10.1109/TEM.2019.2963489

Ferreira, M. (2011). A bibliometric study on Ghoshal's managing across borders. Multinational Business Review, 19(4), 357-375.

Fisher, G., Kotha, S. \& Lahiri, A. (2016). Changing with the times: An integrated view of legitimacy, logics and new venture lifecycles. Academy of Management Review, 41(3), 383-409.

Foreman-Peck, J. \& Zhou, P. (2013). The strength and persistence of entrepreneurial cultures. Journal of Evolutionary Economics, 23, 163 - 187.

Fraser, S. (2009). Is there ethnic discrimination in the UK market for small business credit? International Small Business Journal, 27(5), 583-607.

Frederking, L. C. (2004). A cross-national study of culture, organization and entrepreneurship in three neighbourhoods. Entrepreneurship \& Regional Development, 16(3), 197-215.

Furrer, O., Thomas, H. \& Goussevskaia, A. (2008). The structure and evolution of the strategic management field: A content analysis of 26 years of strategic management research. International Journal of Management Reviews, 10(1), 1-23.

George, G. \& Zahra, S. A. (2002). Culture and its consequences for entrepreneurship. Entrepreneurship: Theory and Practice, 26, 27-29.

Gilal et.al (2019). The role of self-determination theory in marketing science: An integrative review and agenda for research. European Management Journal, 37(1), 29-44.

Gill, R. \& Larson, G. S. (2014). Making the ideal (local) entrepreneur: Place and the regional development of high-tech entrepreneurial identity. Human Relations, 67(5), 519-542.

Glinka, B., \& Brzozowska, A. (2015). Immigrant entrepreneurs: In search of identity. Entrepreneurial Business and Economics Review, 3(3), 51-76. 
Gonzalez-Loureiro, M., Dabic, M., \& Furrer, O. (2015b). A content and comparative analysis of strategic management research in the Baltic area: A research agenda for qualitative studies. Baltic Journal of Management, 10(2), 243-266.

Gonzalez-Loureiro, M., Dabic, M., \& Kiessling, T. (2015a). Supply chain management as the key to a firm's strategy in the global marketplace: Trends and research agenda. International Journal of Physical Distribution \& Logistics Management, 45(1/2), 159-181.

Graneheim, U. H. \& Lundman, B. (2004), Qualitative content analysis in nursing research: concepts, procedures and measures to achieve trustworthiness, Nurse Education Today, 24 (2), 105-112.

Hair, J.H. Jr, Anderson, R.E., Tatham, R.L. \& Black, W.C. (1998). Multivariate Data Analysis, 5th edition. Upper Saddle River, NJ: Prentice Hall.

Hamilton, R., Dana, L. P. \& Benfell, C. (2008). Changing cultures: An international study of migrant entrepreneurs. Journal of Enterprising Culture, 16(1), 89-105.

Hart, M., Bonner, K., \& Levie, J. (2016). Global entrepreneurship monitor: United Kingdom 2016 monitoring report, Retrieved from https://www.enterpriseresearch.ac.uk/wpcontent/uploads/2017/07/GEM-UK-2016_final.pdf on 16.07.2019

Hayton, J. C., George, G., \& Zahra, S. A. (2002). National culture and entrepreneurship: A review of behavioral research. Entrepreneurship: Theory and Practice, 26, 33-52.

Head, K., \& Ries, J. (1998). Immigration and trade creation: Econometric evidence from Canada. Canadian Journal of Economics, 31(1), 47-62.

Herman, R. T. \& Smith, R. L. (2010). Immigrant, Inc.: Why Immigrant Entrepreneurs Are Driving the New Economy (and how they will save the American worker). New Jersey: John Wiley \& Sons.

Hoffman, D.L. \& De Leeuw, J. (1992). Interpreting multiple correspondence analysis as a multidimensional scaling method. Marketing Letters, 3(3), 259-272.

Hofstede, G. (2001). Culture's consequences: Comparing values, behaviors, institutions, and organizations across nations ( $2^{\text {nd }}$ ed.). Thousand Oaks, CA: Sage.

Holt, D. H. (1997). A comparative study of values among Chinese and US entrepreneurs: Pragmatic convergence between contrasting cultures. Journal of Business Venturing, 12(6), 483505.

Honig, B. (1998). What determines success? Examining the human, financial, and social capital of Jamaican micro entrepreneurs. Journal of Business Venturing,13(5), 371-394.

Hopp, C., \& Martin, J. (2017). Does entrepreneurship pay for women and immigrants? A 30-year assessment of the socio-economic impact of entrepreneurial activity in Germany. Entrepreneurship \& Regional Development, 29 (5-6), 517-543.

Jones, C. (2001). Co-evolution of entrepreneurial careers, institutional rules and competitive dynamics in American film, 1895-1920. Organization Studies, 22(6), 911-944.

Jones, T., Ram, M., \& Edwards, P. (2006). Ethnic minority business and the employment of illegal immigrants. Entrepreneurship \& Regional Development, 18, 133-150. 
Jones, T., Ram, M., Edwards, P., Kiselinchev, A., \& Muchenje, L. (2012). New migrant enterprise: Novelty or historical continuity? Urban Studies, 49(14), 159-3176.

Jones, T., Ram, M., Edwards, P., Kiselinchev, A., \& Muchenje, L. (2014). Mixed embeddedness and new migrant enterprise in the UK. Entrepreneurship \& Regional Development, 26(5-6), 500520.

Kalnins, A., \& Chung, W. (2006). Social capital, geography, and survival: Gujarati immigrant entrepreneurs in the US lodging industry. Management Science, 52(2), 233 - 247.

Katila, S., \& Wahlbeck, Ö. (2012). The role of (transnational) social capital in the start-up processes of immigrant businesses: The case of Chinese and Turkish restaurant businesses in Finland. International Small Business Journal, 30(3), 294-309.

Kerr, S. P., \& Kerr, W. R. (2016). Immigrants play a disproportionate role in American entrepreneurship. Harvard Business Review, Retrieved from https://hbr.org/2016/10/immigrants-play-a-disproportionate-role-in-american-entrepreneurship on 16.07.2019.

Keupp, M. M., Palmié, M., \& Gassmann, O. (2012). The strategic management of innovation: A systematic review and paths for future research. International Journal of Management Reviews, 14(4), 367-390.

Khanna, T., \& Palepu, K. G. (2006). Emerging giants: Building world-class companies in developing countries. Harvard Business Review, 84(10), 60-69.

Kiessling, T., Vlačić, B., \& Dabić, M. (2019). Mapping the Future of Cross-Border Mergers and Acquisitions: A Review and Research Agenda. IEEE Transactions on Engineering Management. published online ahead of print, doi: 10.1109/TEM.2019.2954799

Kloosterman, R.C. (2010). Matching opportunities with resources: A framework for analyzing (migrant) entrepreneurship from a mixed embeddedness perspective. Entrepreneurship and Regional Development, 22(1), 25-45.

Kloosterman, R.C., \& Rath, J. (2001). Immigrant entrepreneurs in advanced economies: Mixed embeddedness further explored. Journal of Ethnic and Migration Studies, 27(2), 189-201.

Kloosterman, R.C., van der Leun, J. P., \& Rath, J. (1999). Mixed embeddedness: (In)formal economic activities and immigrant businesses in the Netherlands. International Journal of Urban and Regional Research, 23(2), 252-266.

Koning, J., \& Verver, M. (2013). Historicizing the 'ethnic' in ethnic entrepreneurship: The case of the ethnic Chinese in Bangkok. Entrepreneurship \& Regional Development, 25(5-6), 325-348.

Krueger, J. N. F., Reilly, M. D., \& Carsrud, A. L. (2000). Competing models of entrepreneurial intentions. Journal of Business Venturing, 15(5-6), 411-432.

Kumar, A., Paul, J \& Unnithan, A. (2019). Masstige Marketing: A Review, Synthesis and Research Agenda. Journal of Business Research, forthcoming: doi.org/10.1016/j.jbusres.2019.09.030

Kushnirovich, N., Heilbrunn, S., \& Davidovich, L. (2018). Diversity of entrepreneurial perceptions: Immigrants vs. native population. European Management Review, 15(3), 341-355. 
Leung, M. W. H. (2002). From four-course Peking duck to take-away Singapore rice: An inquiry into the dynamics of the ethnic Chinese catering business in Germany. International Journal of Entrepreneurial Behaviour \& Research, 8(1/2), 134-147.

Levie, J. (2007). Immigration, in-migration, ethnicity and entrepreneurship in the United Kingdom. Small Business Economics, 28, 143-169.

Levitt, P. (1998). Social remittances: Migration driven local-level forms of cultural diffusion. International Migration Review, 32(4), 926-948.

Light, I, Rezaei, S. \& Dana, L.P. (2013). Ethnic minority entrepreneurs in the international carpet trade: an empirical study. International Journal of Entrepreneurship and Small Business, 18(2), $125-153$.

Light, I. (1972). Ethnic enterprise in America. Berkeley, Los Angeles, London: University of California Press.

Light, I., \& Dana, L.P. (2013). Boundaries of social capital in entrepreneurship. Entrepreneurship: Theory \& Practice, 37(3), 603-624.

Light, I., \& Gold, S. (2000). Ethnic economies. San Diego, San Francisco, London. Academic Press.

Light, I., \& Rosenstein, C. (1995). Race, ethnicity, and entrepreneurship in urban America. New York: Aldine De Gruyter.

Light, I., Bhachu, P., \& Karageorgis, S. (1993). Migration networks and immigrant entrepreneurship. In I. Light \& P. Bhachu (Eds.), Immigration and entrepreneurship. Culture, capital and ethnic networks (pp. 25-49). New Brunswick, USA and London UK: Transaction Publishers.

Lin, X., \& Yang, X. (2017). From human capital externality to entrepreneurial aspiration: Revisiting the migration-trade linkage. Journal of World Business, 52(3), 360-371.

Littlewood, D., \& Holt, D. (2018). Social entrepreneurship in South Africa: Exploring the influence of environment. Business \& Society, 57(3), 525-561.

Mahalingam, R. E. (2006). Cultural psychology of immigrants. Lawrence Erlbaum Associates Publishers.

Marvel, M. R., Davis, J. L., \& Sproul, C. R. (2016). Human capital and entrepreneurship research: A critical review and future directions. Entrepreneurship: Theory and Practice, 40(3), 599-626.

McHenry, J. E., \& Welch, D. E. (2018). Entrepreneurs and internationalization: A study of Western immigrants in an emerging market. International Business Review, 27(1), 93-101.

McKnight, B., \& Zietsma, C. (2018). Finding the threshold: A configurational approach to optimal distinctiveness. Journal of Business Venturing, 33(March), 493-512.

Merigó, J. M., Mas-Tur, A., Roig-Tierno, N., \& Ribeiro-Soriano, D. (2015). A bibliometric overview of the Journal of Business Research between 1973 and 2014. Journal of Business Research, 68(12), 2645-2653.

Millar, C. C. J. M. and C. J. Choi, (2008). Worker identity, the liability of foreignness, the exclusion of local managers and unionism: A conceptual analysis. Journal of Organizational Change Management, 21: 460-470. 
Morokvasic, M. (1993). Immigrants in garment production in Paris and in Berlin. In I. Light \& P. Bhachu (Eds.), Immigration and entrepreneurship. Culture, capital and ethnic networks. New Brunswick, USA \& London, UK: Transaction Publishers.

Morris, M., \& Schindehutte, M. (2005). Entrepreneurial values and the ethnic enterprise: An examination of six subcultures. Journal of Small Business Management, 43(4), 453-479.

Mueller, E. (2014). Entrepreneurs from low-skilled immigrant groups in knowledge-intensive industries: company characteristics, survival and innovative performance. Small Business Economics, 42(4), 871-889.

Murzacheva, E., Sahasranamam, S., \& Levie, J. (2019). Doubly disadvantaged: Gender, spatially concentrated deprivation and nascent entrepreneurial activity. European Management Review, forthcoming: https://doi.org/10.1111/emre.12370.

Nahapiet, J., \& Ghoshal, S. (1998). Social capital, intellectual capital and the organizational advantage. Academy of Management Review, 23(2), 242-266.

Nazareno, J., Zhou, M. \& You, T. (2018). Global dynamics of immigrant entrepreneurship: Changing trends, ethnonational variations, and reconceptualizations. International Journal of Entrepreneurial Behavior \& Research. 25(5), 780-800.

Ndofor, H. A., \& Priem, R. L. (2011). Immigrant entrepreneurs, the ethnic enclave strategy, and venture performance. Journal of Management, 37(3), 790-818.

Nee, V., \& Sanders, J. (2001). Understanding the diversity of immigrant incorporation: A formsof-capital model. Ethnic and Racial Studies, 24(3), 386-411.

North, D. C. (1990). Institutions, institutional change and economic performance. Cambridge University Press.

Ohlsson, H., Broomé, P., \& Bevelander, P. (2012). Self-employment of immigrants and natives in Sweden - a multilevel analysis. Entrepreneurship \& Regional Development, 24(5-6), 405-423.

Oliveira, C. R. (2007). Understanding the diversity of immigrant entrepreneurial strategies. In L. P. Dana (Ed.), Handbook of research on ethnic minority entrepreneurship. A Co-evolutionary view on resource management (pp. 61-82). Cheltenham, UK, Northampton, MA, USA: Edwarg Elgar.

Oswick, C., Fleming, P., \& Hanlon, G. (2011). From Borrowing to Blending: Rethinking the processes of organizational theory building. Academy of Management Review, 36(2), 318-337.

Patterson, S. (1963), Dark Strangers: A Sociological Study of a Recent West Indian Migrant Group in Brixton, South London, London: Tavistock.

Paul, J. (2019). Marketing in emerging markets: a review, theoretical synthesis and extension. International Journal of Emerging Markets, forthcoming: https://doi.org/10.1108/IJOEM-04-2017-0130.

Paul, J. (2020). SCOPE Framework for SMEs. A New theoretical lens for success and internationalization. European Management Journal, forthcoming: https://doi.org/10.1016/j.emj.2020.02.001 
Paul, J., \& Benito, G. R. (2018). A review of research on outward foreign direct investment from emerging countries, including China: What do we know, how do we know and where should we be heading? Asia Pacific Business Review, 24(1), 90-115.

Paul, J., \& Mas, E. (2019). Toward a 7-P framework for international marketing. Journal of Strategic Marketing, forthcoming:

https://doi.org/10.1080/0965254X.2019.1569111

Paul, J., \& Rosado-Serrano, A. (2019). Gradual Internationalization vs Born-Global/International new venture models: A review and research agenda. International Marketing Review. 36(6), 830858 .

Paul, J., \& Shrivatava, A. (2016). Do young managers in a developing country have stronger entrepreneurial intentions? Theory and debate. International Business Review, 25(6), 1197-1210.

Paul, J., \& Singh, G. (2017). The 45 years of foreign direct investment research: Approaches, advances and analytical areas. The World Economy, 40(11), 2512-2527

Paul, J., Parthasarathy, S., \& Gupta, P. (2017). Exporting challenges of SMEs: A review and future research agenda. Journal of World Business, 52(3), 327-342.

Pécoud, A. (2004). Entrepreneurship and identity: cosmopolitanism and cultural competencies among German-Turkish businesspeople in Berlin. Journal of Ethnic and Migration studies, 30(1), 3-20.

Peroni, C., Riillo, C. A. F., \& Sarracino, F. (2016). Entrepreneurship and immigration: Evidence from GEM Luxembourg. Small Business Economics, 46(4), 639-656.

Pfeffer, M. J., \& Parra, P. A. (2009). Strong ties, weak ties, and human capital: Latino immigrant employment outside the enclave. Rural Sociology, 74(2), 241-269.

Pio, E., Essers, C. (2014). Professional Migrant Women Decentring Otherness: A Transnational Perspective. British Journal of Management, 25(2), 252-265.

Podsakoff, P., Mackenzie, S., Bachrach, D., \& Podsakoff, N. (2005). The influence of management journals in the 1980s and 1990s. Strategic Management Journal, 26, 473-488.

Poggesi, S., Mari, M., \& De Vita, L. (2016). What's new in female entrepreneurship research? Answers from the literature. International Entrepreneurship and Management Journal, 12(3), 735-764.

Portes, A., \& Jensen, L. (1989). The enclave and the entrants: Patterns of ethnic enterprise in Miami and After Mariel. American Sociological Review, 54(December), 929-949.

Portes, A., \& Rumbaut, R. G. (2006). Immigrant America. A portrait (III ed.). Berkley, Los Angeles, London: University of California Press.

Portes, A., \& Sensenbrenner, J. (1993). Embeddedness and immigration: Notes on the social determinants of economic action. American Journal of Sociology, 98(6), 1320-1350.

Portes, A., \& Zhou, M. (1993). The new second generation: Segmented assimilation and its variants among post-1965 immigrant youth. Annals of the American Academy of Political and Social Sciences, 530(Nov.), 74-98.

Portes, A., \& Zhou, M. (1996). Self-employment and the earnings of immigrants. American Sociological Review, 61(2), 219-230. 
Portes, A., Guarnizo, L. E., \& Haller, W. J. (2002). Transnational entrepreneurs: An alternative form of immigrant economic adaptation. American Sociological Review, 67(2), 278-298.

Qin, F., \& Estrin, S. (2015). Does social influence span time and space? Evidence from Indian returnee entrepreneurs. Strategic Entrepreneurship Journal, 9(3), 226-242.

Ram, M., Jones, T., \& Villares-Varela, M. (2017). Migrant entrepreneurship: Reflections on research and practice. International Small Business Journal, 35(1), 3-18.

Ram, M., Jones, T., Edwards, P., Kiselinchev, A., Muchenje, L. \& Woldesenbet, K. (2013). Engaging with super-diversity: New migrant businesses and the research-policy nexus. International Small Business Journal, 31(4): 337-356.

Randhawa, K., Wilden, R., \& Hohberger, J. (2016). A bibliometric review of open innovation: Setting a research agenda. Journal of Product Innovation Management, 33(6), 750-772

Rath, J., \& Kloosterman, R. (2000). Outsiders' business: A critical review of research on immigrant entrepreneurship. International Migration Review, 34(3), 657-681.

Riddle, L., Hrivnak, G. A., \& Nielsen, T. M. (2010). Transnational diaspora entrepreneurship in emerging markets: Bridging institutional divides. Journal of International Management, 16(4), 398-411.

Rivera-Santos, M., Holt, D., Littlewood, D., \& Kolk, A. (2015). Social entrepreneurship in SubSaharan Africa. Academy of Management Perspectives, 29(1), 72-91.

Robinson, W. S. (1950). Ecological correlations and the behavior of individuals. American Sociological Review, 15(3), 351-357.

Rosado-Serrano, A., Paul, J., \& Dikova, D. (2018). International franchising: A literature review and research agenda. Journal of Business Research, 85, 238-257.

Sahasranamam, S. \& Sud, M. (2016). Opportunity and necessity entrepreneurship: A comparative study of India and China. Academy of Entrepreneurship Journal, 22(1), 21-40.

Sahasranamam, S., \& Ball, C. (2018). National context matters: Influence of national business system on social enterprises in Scotland and India. In L. J. Spence, J. G. Frynas, J. N. Muthuri, \& J. Navare (Eds.), Research Handbook on Small Business Social Responsibility: Global perspectives (pp. 23-46). Cheltenham, UK: Edward Elgar.

Sahasranamam, S., \& Nandakumar, M. K. (2018). Individual capital and social entrepreneurship: Role of formal institutions. Journal of Business Research, available online ahead of print: https://doi.org/10.1016/j.jbusres.2018.09.005

Sanders, J. M., \& Nee, V. (1996). Immigrant self-employment: The family as social capital and the value of human capital. American Sociological Review, 61(2), 231-249.

Saxenian, A. (2002). Silicon Valley's new immigrant high-growth entrepreneurs. Economic Development Quarterly, 16(1), 20-31.

Schøtt, T. (2018). Entrepreneurial pursuits in the Caribbean diaspora: networks and their mixed effects. Entrepreneurship \& Regional Development, 30(9-10), 1069-1090.

Sepulveda, L., Syrett, S., \& Lyon, F. (2011). Population superdiversity and new migrant enterprise: The case of London. Entrepreneurship \& Regional Development, 23(7-8), 469-497. 
Shafique, N. (2013). Thinking inside the box? Intellectual structure of the knowledge base innovation research (1988-2008). Strategic Management Journal, 34(1), 62-93

Shinnar, R. S., Aguilera, M. B., \& Lyons, T. S. (2011). Co-ethnic markets: Financial penalty or opportunity? International Business Review, 20(6), 646-658.

Sinkovics, N. (2016) Enhancing the foundations for theorizing through bibliometric mapping, International Marketing Review, 33(3), 327-350

Smallbone, D., Bertotti, M., \& Ekanem, I. (2005). Diversification in ethnic minority business: The case of Asians in London's creative industries. Journal of Small Business and Enterprise Development, 12(1), 41-56.

Smallbone, D., Dabic, M., \& Kalantaridis, C. (2017). Migration, entrepreneurship and economic development. Entrepreneurship and Regional Development, 29 (5-6), 567-569.

Storti, L. (2014). Being an entrepreneur: emergence and structuring of two immigrant entrepreneur groups. Entrepreneurship \& Regional Development, 26(7-8), 521-545.

Stoyanov, S. (2018). Enabling Social Identity Interaction: Bulgarian Migrant Entrepreneurs Building Embeddedness into a Transnational Network. British Journal of Management, 29(2), 373-388.

Sui, S., Morgan, H. M., \& Baum, M. (2015). Internationalization of immigrant-owned SMEs: The role of language. Journal of World Business, 50(4), 804-814.

Sundararajan, M. and Sundararajan B. (2015). Immigrant capital and entrepreneurial opportunities. Entrepreneurial Business and Economics Review, 3(3), 29-50.

Terjesen, S., Hessels, J., \& Li, D. (2016). Comparative international entrepreneurship: A review and research agenda. Journal of Management, 42(1), 299-344.

Urbano, D., Toledano, N., \& Ribeiro-Soriano, D. (2011). Socio-cultural factors and transnational entrepreneurship. International Small Business Journal, 29(2), 119-134.

Vertovec, S. (2007). Super-diversity and its implications. Ethnic and Racial Studies, 30(6), 10241054.

Vinogradov, E., \& Kolvereid, L. (2007). Cultural background, human capital and self-employment rates among immigrants in Norway. Entrepreneurship \& Regional Development, 19(4), 359376.

Volery, T. (2007). Ethnic entrepreneurship: A theoretical framework. In L. P. Dana (Ed.), Handbook of research on ethnic minority entrepreneurship. A co-evolutionary view on resource management. (pp. 30-41). Cheltenham, UK, Northampton, MA USA: Edward Elgar.

Vorderwulbecke, A. (2013). Entrepreneurship and migration. In S. R. Xavier, D. Kelley, J. Kew, M. Herrington, \& A. Vorderwulbecke (Eds.), Global Entrepreneurship Monitor. 2012 Global report (pp. 42-50): Global Entrepreneurship Research Association (GERA).

Waldinger, R. D. (1984). Immigrant Enterprise in the New York Garment Industry, Social Problems 32 (1), 60-71.

Waldinger, R. D. (1995). The "other side" of embeddedness: A case-study of the interplay of economy and ethnicity. Ethnic and Racial Studies, 18(3), 555-580. 
Wang, C. L., \& Altinay, L. (2012). Social embeddedness, entrepreneurial orientation and firm growth in ethnic minority small businesses in the UK. International Small Business Journal, 30(1), 3-23.

Wang, Y., \& Warn, J. (2017). Chinese immigrant entrepreneurship: Embeddedness and the interaction of resources with the wider social and economic and context. International Small Business Journal, 131-148.

Ward, R. \& Jenkins, R. (1984). Ethnic Communities in Business: Strategies for Economic Survival, Cambridge: Cambridge University Press.

Wennberg, K., Pathak, S., \& Autio, E. (2013). How culture moulds the effects of self-efficacy and fear of failure on entrepreneurship. Entrepreneurship \& Regional Development, 25(9-10), 756780 .

Wong, L. L., \& Ng, M. (2002). The emergence of small transnational enterprise in Vancouver: The case of Chinese entrepreneur immigrants. International Journal of Urban and Regional Research, 26(3), 508-530.

Woodruff, C., \& Zenteno, R. (2007). Migration networks and microenterprises in Mexico. Journal of Development Economics, 82, 509-528.

Yang, C., Colarelli, S. M., Han, K., \& Page, R. (2011). Start-up and hiring practices of immigrant entrepreneurs: An empirical study from an evolutionary psychological perspective. International Business Review, 20(6), 636-645.

Yang, X., Ho, E. Y. H., \& Chang, A. (2012). Integrating the resource-based view and transaction cost economics in immigrant business performance. Asia Pacific Journal of Management, 29(3), 753-772.

Zhang, J., Wong, P. K., \& Ho, Y. P. (2016). Ethnic enclave and entrepreneurial financing: Asian venture capitalists in Silicon Valley. Strategic Entrepreneurship Journal, 10(3), 318-335.

Zhou, M. (2009). Contemporary Chinese America. Immigration, ethnicity, and community transformation. Philadelphia: Temple University Press.

Zimmer, C., \& Aldrich, H. (1987). Resource mobilization through ethnic networks: Kinship and friendship ties of shopkeepers in England. Sociological Perspectives, 30(4), 422-445. 


\section{ID: JBR-D-19-03808I \\ MMIGRANT ENTREPRENEURSHIP: A REVIEW AND RESEARCH AGENDA Tables and Figures}

Figure 1 (on page 5): Methodology protocol

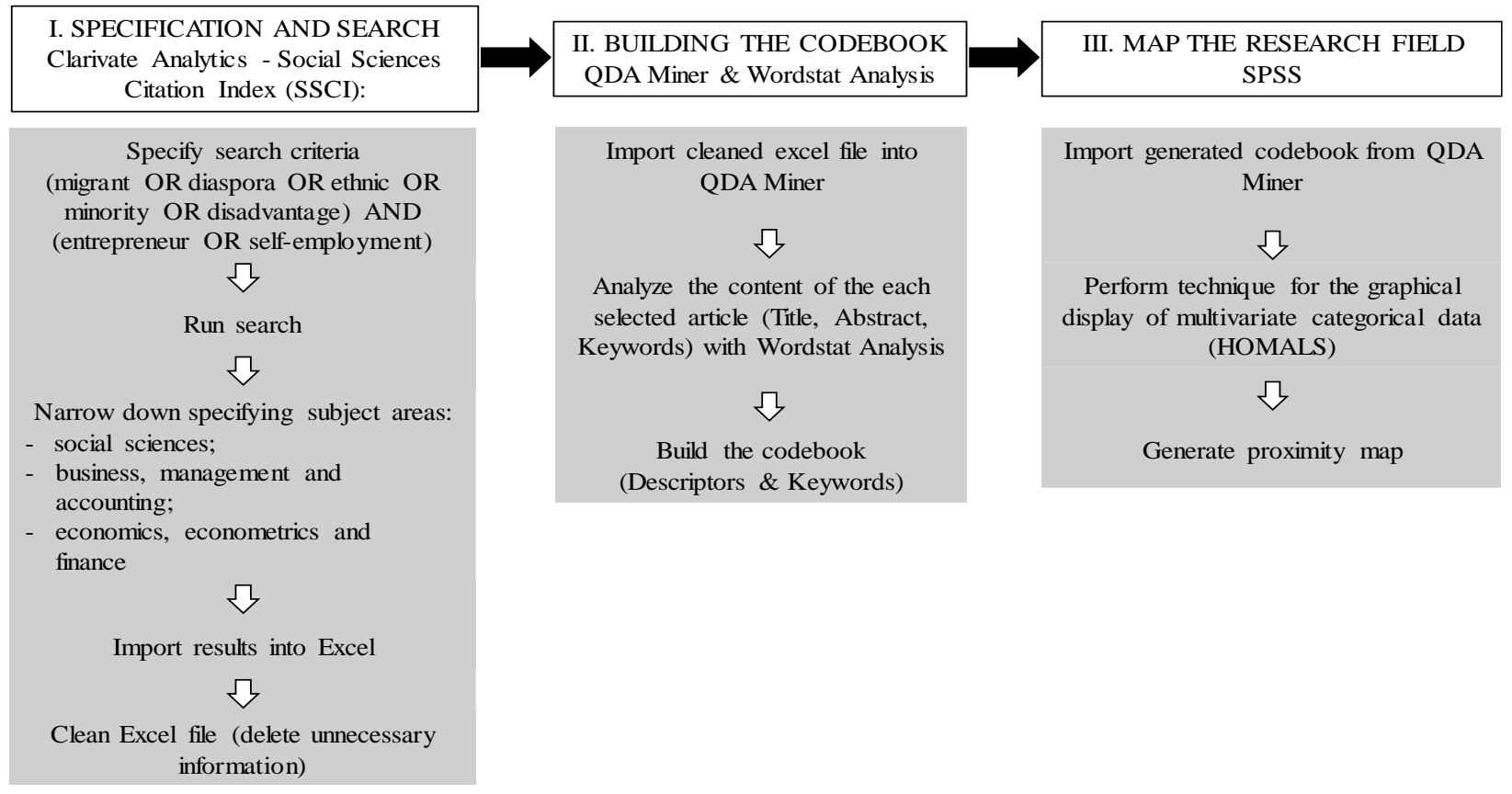

Source: own draft 
Figure 2 : Map of the immigrant entrepreneurship research field

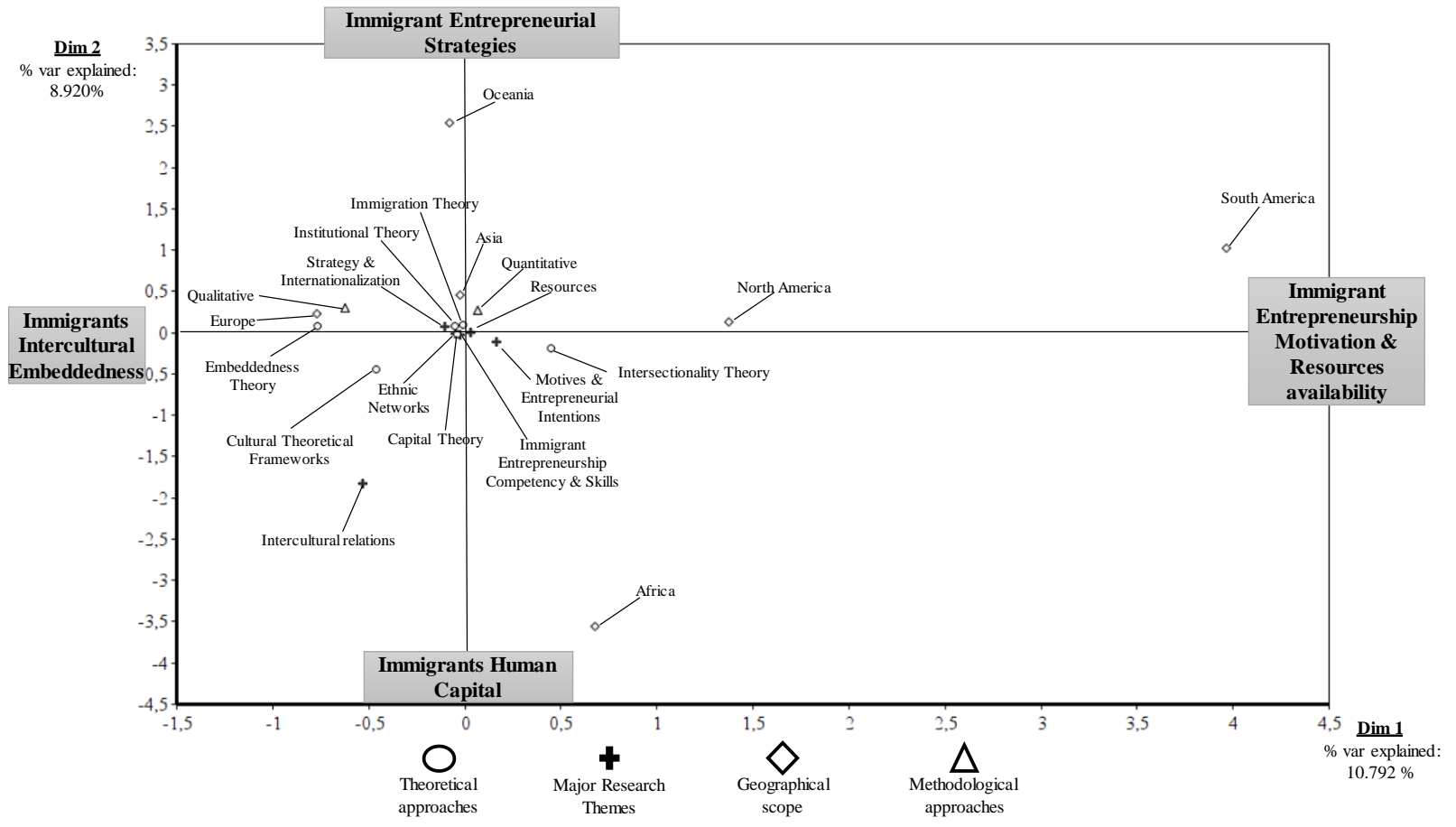

Source: own draft 
Figure 3 : Conceptual framework

\section{External environment influencers (country of ethnic origin/ immigrated country)}

Main theories used - Institutional theory, Cultural theoretical frameworks

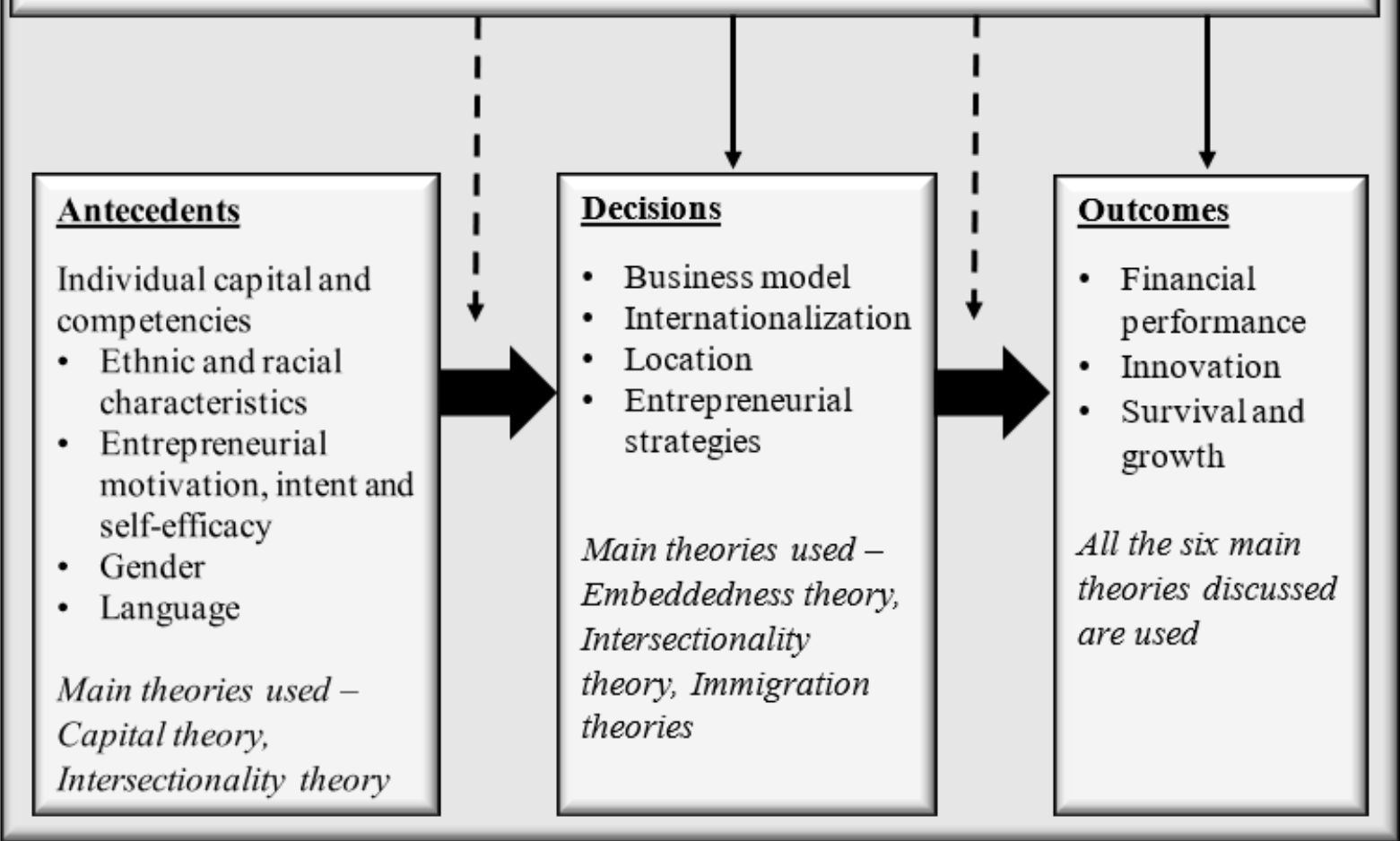


Table 1 : Descriptors that represent the poles of the axes

\begin{tabular}{|c|c|c|c|}
\hline Axes & Descriptor & Origin of the axes descriptor & Notable studies \\
\hline Axis X Left & $\begin{array}{l}\text { Immigrants } \\
\text { Intercultural } \\
\text { Embeddedness }\end{array}$ & $\begin{array}{l}\text { Embeddedness Theory; } \\
\text { Intercultural Relations; Cultural } \\
\text { Frameworks }\end{array}$ & $\begin{array}{l}\text { Holt, 1997; Kloosterman, 2010; } \\
\text { Schøtt, } 2018\end{array}$ \\
\hline Axis X Right & $\begin{array}{l}\text { Immigrant } \\
\text { Entrepreneurship } \\
\text { Motivation \& } \\
\text { Resources } \\
\text { availability }\end{array}$ & $\begin{array}{l}\text { Resources; Motives and } \\
\text { Entrepreneurial Intentions; } \\
\text { Intersectionality Theory }\end{array}$ & $\begin{array}{l}\text { Krueger et al., 2000; Kloosterman e } \\
\text { al., 1999; Edelman et al., } 2010\end{array}$ \\
\hline Axis Y Upper & $\begin{array}{l}\text { Immigrant } \\
\text { Entrepreneurial } \\
\text { Strategies }\end{array}$ & $\begin{array}{l}\text { Immigration Theory; Strategies and } \\
\text { Internationalization; Institutional } \\
\text { Theory }\end{array}$ & $\begin{array}{l}\text { Bhalla et al., 2006; Riddle et al., } \\
\text { 2010; McHenry and Welch, } 2018\end{array}$ \\
\hline Axis Y Lower & $\begin{array}{l}\text { Immigrants } \\
\text { Human Capital }\end{array}$ & $\begin{array}{l}\text { Capital Theory; Immigrant } \\
\text { Entrepreneurship Competency and } \\
\text { Skills; Ethnic Networks }\end{array}$ & $\begin{array}{l}\text { Honig, 1998; Pécoud, 2004; Pfeffer } \\
\text { and Parra, } 2009\end{array}$ \\
\hline
\end{tabular}

